Article

\title{
Investigation of Heating and Freezing Pretreatments on Mechanical, Chemical and Spectral Properties of Bulk Sunflower Seeds and Oil
}

\author{
Gürkan Alp Kağan Gürdil ${ }^{1, *}{ }^{\circledR}$, Abraham Kabutey ${ }^{1} \oplus$, Kemal Çağatay Selvi ${ }^{1}$, Petr Hrabě ${ }^{2}$, \\ David Herák ${ }^{1} \mathbb{B}$ and Adéla Fraňková ${ }^{3}$ \\ 1 Department of Mechanical Engineering, Faculty of Engineering, Czech University of Life Sciences Prague, \\ 16521 Prague, Czech Republic; kabutey@tf.czu.cz (A.K.); kcselvi@omu.edu.tr (K.C.S.); herak@tf.czu.cz (D.H.) \\ 2 Department of Materials and Manufacturing Technology, Faculty of Engineering, Czech University of Life \\ Sciences Prague, 16521 Prague, Czech Republic; hrabe@tf.czu.cz \\ 3 Department of Food Science, Faculty of Agrobiology, Food and Natural Resources, Czech University of Life \\ Sciences Prague, 16521 Prague, Czech Republic; frankovaa@af.czu.cz \\ * Correspondence: ggurdil@omu.edu.tr; Tel.: +90-362-312-1919
}

Received: 19 March 2020; Accepted: 26 March 2020; Published: 31 March 2020

\begin{abstract}
The present study examined the effects of heating and freezing pretreatments on the mechanical, chemical, and spectral characteristics of sunflower seeds and oil under a linear compression process involving a universal compression-testing machine and a pressing vessel of diameter $60 \mathrm{~mm}$ with a plunger. The heating temperatures ranged from 40 to $80{ }^{\circ} \mathrm{C}$ and freezing temperatures from -2 to $-36^{\circ} \mathrm{C}$ at constant heating time of $30 \mathrm{~min}$. The pretreated samples of initial height of $80 \mathrm{~mm}\left(22.6 \times 10^{-5} \mathrm{~m}^{3}\right)$ were compressed under a preset load of $100 \mathrm{kN}$ and a speed of $5 \mathrm{~mm} / \mathrm{min}$. The results showed that oil expression efficiency significantly increased $(p<0.05)$ with increased heating temperatures but decreased with freezing temperatures. The lowest energy per volume oil of $22.55 \pm 0.919 \mathrm{~kJ} / \mathrm{L}$ was recorded at $80{ }^{\circ} \mathrm{C}$ compared to $26.40 \pm 0.307 \mathrm{~kJ} / \mathrm{L}$ noticed at $-2{ }^{\circ} \mathrm{C}$ and control $\left(25^{\circ} \mathrm{C}\right)$ of $33.93 \pm 3.866 \mathrm{~kJ} / \mathrm{L}$. The linear regression equations expressing oil expression efficiency, energy per volume oil, peroxide value, and free fatty acid, dependent on heating and freezing temperatures, were described with coefficients of determination between 0.373 and 0.908 . Increased heating temperatures increased the UV absorption rate of the oil samples at a wavelength of $350 \mathrm{~nm}$. The study is part of the continuing research on linear compression modeling of all processing factors, whereby the results are intended to be applied to the non-linear process dealing with a mechanical screw press to improve the oil extraction process.
\end{abstract}

Keywords: oil-bearing crop; linear compression; oil expression efficiency; energy demand; oil quality

\section{Introduction}

Sunflower (Helianthus annus L.), a member of the Asteraceae family, is among the top five oil crops cultivated worldwide and is the third most important oilseed crop after soybean and rapeseed [1,2]. Among these crops, sunflower seeds are advantageous since they contain low amounts of allergen factors, anti-nutritional, and toxic compounds, such as toxic cyanogens and saponins [3,4]. The sunflower seed is a rich source for oil whiles the seedcake or meal, rich in protein and fibres, is a by-product used as animal feed [5-9].

Currently, the most commonly used method of processing oilseeds is pre-press solvent extraction. The seeds are screw-pressed until the maximum oil is expressed, and subsequently, the seedcake is subjected to solvent extraction to obtain the residual oil $[2,10,11]$. Comparatively, mechanical screw press has been the oldest technique for extracting edible and non-edible oils from oil feedstocks 
due to many advantages including easy operation, semi-skilled operators and solvent-free oil and seedcake [12-15]. However, the technique is not considered efficient as the oil recovery efficiency is low and between $5 \%$ and $15 \%$ of available oil is left in the seedcake [16-19]. On the other hand, solvent extraction has become a widespread process of oil extraction due to the high percentage oil yield and being an effective method of extracting oil for biodiesel production [20,21]. While the raw materials (species, moisture content, pretreatment), press and screw configurations, and operating conditions (screw and barrel feeding, screw rotation speed, pressure, and opening choke adjustment) affect the oil expression with mechanical screw presses [16,18,22-24], the nature of the solvent, temperature, agitation intensity, reaction time, the reaction between the solvent and the kernel, the particle size of the feedstock, and solid/solvent ratio thus influence the solvent extraction method [25-30].

Heating and freezing are alternative pre-treatment methods for reducing the initial moisture content and maintaining the initial quality [31-33]. Both methods could alter the mechanical properties of the cell material/microstructure and improve processing properties [34-37]. Heat-treatment of oilseed has been observed to rupture the oil-bearing cells, coagulate the protein in the meal, adjust the moisture to an optimum level, lower the viscosity and increase the fluidity of the oil and destroy mould and bacteria, thereby facilitating oil expression from the oil-bearing material [38-41]. The rapid nature of a product subjected to frozen determines the size of crystals formed, and the degree of structural change that may occur. Large ice crystals are synonymous with mechanical damage, significant drip loss and structural deformation of the cellular structure of many biological materials [42-45]. The quality of extra virgin olive oil by three different methods including blast freezing at $-25{ }^{\circ} \mathrm{C}$ has been studied [46]. The authors reported that the oils from frozen olive retained the commercial extra virgin grade comparable to the control oil despite a slight increment in the peroxide values. [34], also conducted a study on the effect of freezing-thawing pretreatment combined with liquid nitrogen and dilute acid on the gelatinization of collagen. They indicated that the freezing-thawing process could not effectively induce the gelatinization of collagen. However, the freezing-thawing method with $1 \% \mathrm{HCl}$ produced the gelatin with the highest yield and gel strength. Meanwhile, [47] also evaluated the influence of olives freezing on the biochemical factors, and found that freezing of the olives induced the biochemical changes resulting in a significant modification of the main compounds responsible for the sensorial properties of virgin olive oil. Different physical and chemical properties of vegetable oils, such as acidity, density, viscosity, color, refractive index, moisture, volatility, dielectric constant, total polar compounds, saponification, peroxide, free fatty acids, iodine ester, and carbonyl values, thus determine the quality and stability of oils and these parameters greatly vary in temperature [1,48-52]. Peroxide value is an indicator of the initial stages of oxidation and measures the number of total peroxides in a substance. It is considered one of the most frequently determined quality parameters during oil production, storage and marketing, and a useful indicator to control food quality and safety [53-55]. The radical species formed in the peroxidation process degrade fatty acids and other components of the lipids [56]. The oxidative susceptibility of lipids is correlated with their fatty acid composition, especially the degree of unsaturation of lipids [57]. Sunflower oil contains high levels of saturated fatty acids and unsaturated fatty acids. Therefore, the quality properties of the oil are of paramount importance for human consumption and industrial applications [58].

Several attempts have been considered for optimizing oil extraction using the mechanical screw press. These include modification of the screw profile/configuration (using a twin-screw instead of a single screw), design of input parameters (screws with choke worm shaft ring sizes, press cylinders with mesh sizes, nozzles with restriction sizes), and sensors for measuring direct and indirect parameters such as temperature, pressure, torque, and rotational speed $[23,59,60]$. Other authors have evaluated the die diameter, preheating temperature of the barrel, and screw rotation speed on oil yield and total polyphenol content of cold-pressed oil [61]. Traditionally, in small-medium scale operations, the mechanical pressing is mostly employed despite its low oil recovery efficiency. The screw profile/configuration is still the main factor influencing the performance of the mechanical pressing. This has renewed interest in new approaches for improving its efficiency. Generally, 
the optimal process of equipment design is fully understood when various processing factors are considerably investigated. These new methods, however, can be first evaluated under the linear compression process involving a universal compression-testing machine and a piston and pressing chamber (containing the volume of material) with holes which allow the oil leakage under a given load and speed [62-66]. In the linear compression process, the dependency between compression force and deformation as well as relaxation force and time can be described. The smooth and serrated patterns on the force and deformation curve with maximum oil recovery and energy demand can fully be understood. This information can be further transferred into the mechanical pressing process by applying the tangent curve model and press configuration parameters to theoretically predict the force, pressure and energy along the screw pressing chambers $[67,68]$.

In linear compression loading, the effects of heating and freezing pre-treatment temperatures on mechanical properties, chemical and spectral properties have not been adequately reported. Therefore, the objectives of the study were to compare the mechanism of heating $\left(40\right.$ to $\left.80^{\circ} \mathrm{C}\right)$ to freezing $(-2$ to $\left.-36^{\circ} \mathrm{C}\right)$ along with the control $\left(25^{\circ} \mathrm{C}\right)$ on the force-deformation curve, relaxation force-time curve, oil yield, oil expression efficiency, deformation energy, energy per volume oil, energy per unit volume of material, peroxide value, free fatty acid and UV absorption, and transmittance of sunflower seeds and oil.

\section{Materials and Methods}

Bulk samples of sunflower oilseeds purchased from Česká Skalice, Czech Republic were used for the compression test experiments. Before the experiments, the samples were kept under laboratory conditions (temperature of $25^{\circ} \mathrm{C}$ and humidity of $30 \%$ ). The quality of the seeds was evaluated based on a visual inspection of moulds, insects, worms, and hulls without seeds where impurities such as leaves, pieces of stalks, and dust were separated.

\subsection{Determination of Moisture Content}

The initial moisture content of the samples was determined using the standard hot air oven method (MEMMERT GmbH $+\mathrm{Co}$. KG, Germany) with a temperature setting of $105^{\circ} \mathrm{C}$ and a drying time of $17 \mathrm{~h}$ [69]. The electronic balance Kern 440-35 (Kern \& Sohn GmbH, Balingen, Germany) with an accuracy of $0.001 \mathrm{~g}$ was used for weighing the samples before and after oven drying. The moisture content of $5.14 \pm 0.38$ (\% w.b.) was calculated based on the relation given by [70].

\subsection{Determination of Oil Content}

The percentage oil content of $33.12 \pm 0.87 \%$ contained in the bulk sunflower oilseeds was determined by a Soxhlet extraction according to the procedure reported by [71,72]. Based on the procedure, a ground sample of mass $8 \mathrm{~g}$ was packed in a thimble and inserted into a Soxhlet extractor connected to a $150 \mathrm{~mL}$ containing $100 \mathrm{~mL}$ of petroleum ether. The oil was extracted for $24 \mathrm{~h}$. After extraction, the oil was dried at $105^{\circ} \mathrm{C}$ for $5 \mathrm{~h}$ to remove residual water and solvent. The oil content of the sample was calculated based on the dry weight of the sample [70].

\subsection{Heating and Freezing Pretreatments}

The bulk samples of sunflower seeds, pressing vessel and plunger were subjected to heating temperatures of 40,60 , and $80{ }^{\circ} \mathrm{C}$ using the conventional oven method (MEMMERT GmbH $+\mathrm{Co}$. KG, Germany) and a heat source connected to the pressing vessel which was maintained throughout the compression process for each pre-heated sample. The freezing temperatures of the samples at $-2,-12$, -22 , and $-36{ }^{\circ} \mathrm{C}$ were done using a blast chiller/freezer (Rev 02_2016-Del 06/2016, Cod. Listrbn, Italy). The time duration of $30 \mathrm{~min}$ was allowed for all pre-treated samples. 


\subsection{Compression Test and Parameters Calculated}

The universal compression-testing equipment (Tempos, ZDM 50, Czech Republic) and a pressing vessel of diameter $60 \mathrm{~mm}$ with a plunger (Figure 1) [73] were used to record the force and deformation curves of the pre-treated samples (measured at an initial height of $80 \mathrm{~mm}$, of the volume of $22.6 \times 10^{-5} \mathrm{~m}^{3}$ ) at a maximum load of $100 \mathrm{kN}$ and speed of $5 \mathrm{~mm} / \mathrm{min}$. The volume of samples was calculated according to the relation given by $[74,75]$. The deformation DX (mm) of samples was obtained from the compression test data. Oil yield OY $(\%)$ was calculated based on the relation given by [12]. The oil expression efficiency OEE (\%) was calculated according to the relation given by [76]. The deformation energy, DE (J) was calculated according to the relations given by $[62,64]$. The energy per volume oil, EVO, and energy per unit volume, EUV, were calculated according to the relations given by $[9,74]$.
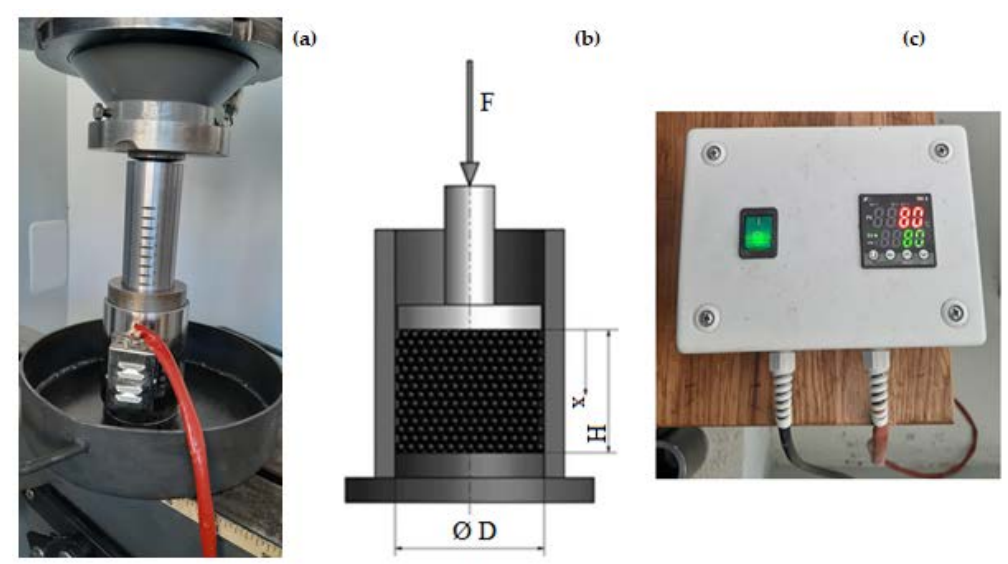

Figure 1. Compression test with (a) vessel diameter with a plunger (b) schematic showing applied force, $\mathrm{F}(\mathrm{kN})$, the initial pressing height of sample, $\mathrm{H}(\mathrm{mm})$ and samples deformation, $\mathrm{x}(\mathrm{mm})$ and (c) connected heat source to the pressing vessel, for instance at a temperature of $80^{\circ} \mathrm{C}$.

\subsection{Spectrophotometric Analysis of Oil Samples}

The sample oils were collected into clean and dried bottles to avoid contamination. The density of the oil was $0.93 \mathrm{~g} / \mathrm{cm}^{3}$. A UV-VIS spectrophotometer (SpektrofotometrOnda VIS V-10 Plus, Czech Republic) was used to describe the spectral curves (absorbance and transmittance) of the oil samples at wavelengths between 300 and $800 \mathrm{~nm}$. This was to measure the incident light absorbed and light transmitted through the oil samples which can be used for UV radiation problems on human health [77]. The measurements were done one after the other by cleaning the cuvette quartz cell cautiously.

\subsection{Determination of Peroxide Value (PV) and Free Fatty Acid (FFA)}

$5 \mathrm{~g}$ of the oil sample was weighed into a volumetric flask and dissolved in a $30 \mathrm{~mL}$ of chloroform and a glacial acetic acid mixture of ratio (2:3) followed by the addition of a $1 \mathrm{~mL}$ of saturated Potassium Iodine (KI) and left in a dark place for five mins. Afterwards, $40 \mathrm{~mL}$ of distilled water was added and the sample was titrated with $0.1 \mathrm{M} \mathrm{Na}_{2} \mathrm{~S}_{2} \mathrm{O}_{3}$ until the yellow color of the sample almost disappeared. Thereafter a $1 \mathrm{~mL}$ of $1 \%$ starch was added and the sample was again titrated with $\mathrm{Na}_{2} \mathrm{~S}_{2} \mathrm{O}_{3}$ until complete discoloration. Peroxide value was expressed as ( $\mu \mathrm{g} / \mathrm{g}$ of active oxygen) $[1,78]$. For FFA determination, $5 \mathrm{~g}$ of the oil samples was weighted into a titration flask, then a $100 \mathrm{~mL}$ of neutralized ethanol (warmed up to $60-65{ }^{\circ} \mathrm{C}$ ) was added together with a $2 \mathrm{~mL}$ of $1 \%$ phenolphthalein and immediately titrated with an ethanolic $\mathrm{KOH}(0.1 \mathrm{~g} / \mathrm{mol})$ up to light pink color. FFA was expressed as (mg KOH/g) [1,78]. All samples were analyzed in duplicates and the results averaged. 


\subsection{Statistical Analyses}

The data were subjected to descriptive, ANOVA, linear regression and correlation analyses using Statistica 13 [79]. The means were compared by using Duncan and Tukey HSD tests at $95 \%$ significance level for all parameters evaluated in the ANOVA.

\section{Results and Discussion}

\subsection{Force-Deformation and Relaxation Force-Time Curves}

The force-deformation and relaxation-force and time curves are displayed in Figures 2-4 respectively. It can be seen clearly in Figure 2 that, at a maximum force of $100 \mathrm{kN}$ and speed of $5 \mathrm{~mm} / \mathrm{min}$, the sunflower seeds (samples) in relation to heating and freezing temperatures showed smooth curve patterns. Based on the control $\left(25^{\circ} \mathrm{C}\right.$; without heating/freezing), the increase in heating temperatures increased the area under the force-deformation curve (the curves were shifted to the right). On the other hand, the decrease in freezing temperatures decreased the area under the curve (the curves were shifted to the left). The area under the force-deformation curve is theoretically denoted as the deformation energy, DE (J) [62,66]. Additionally, the freezing pretreatment (samples together with the vessel diameter and plunger) showed a serration/undulation effect on the force-deformation curve (Figure 3). The serration effect occurred after $1.4 \mathrm{~min}$ of compression at a maximum force of $1.126 \mathrm{kN}$ with the corresponding deformation, DX of $6.97 \mathrm{~mm}$. Here, there was no leakage of the oil; hence the compression process was discontinued. However, the occurrence of the serration effect could be attributed to the lubricating effect, that is, low friction between the material and the inner wall of the pressing vessel and plunger during the compression process. Nevertheless, the mechanical behaviour of the seeds, higher compression force, speed, moisture content and smaller vessel diameter have been reported to necessitate the serration effect $[9,63,64,80]$. Furthermore, in all tests, the compression process took 13 mins. Afterwards, the relaxation process was allowed for just about $12 \mathrm{~min}$ (Figure 4) to ensure maximum oil output based on a preliminary test. It was observed that the control $\left(25^{\circ} \mathrm{C}\right.$ of the samples without heating but with relaxation) and (with heating at $80^{\circ} \mathrm{C}$ and relaxation) increased the oil expression efficiency by approximately $6 \%$. However, the combined heatingat $80^{\circ} \mathrm{C}$ (samples, vessel diameter and plunger and relaxation process) further increased the oil expression efficiency by $25 \%$. Based on the present study, it was found that the combined heating and relaxation process had a positive impact on oil expression efficiency. The freezing temperatures and relaxation process did not show any significant influence on the oil expression efficiency in comparison with the control.

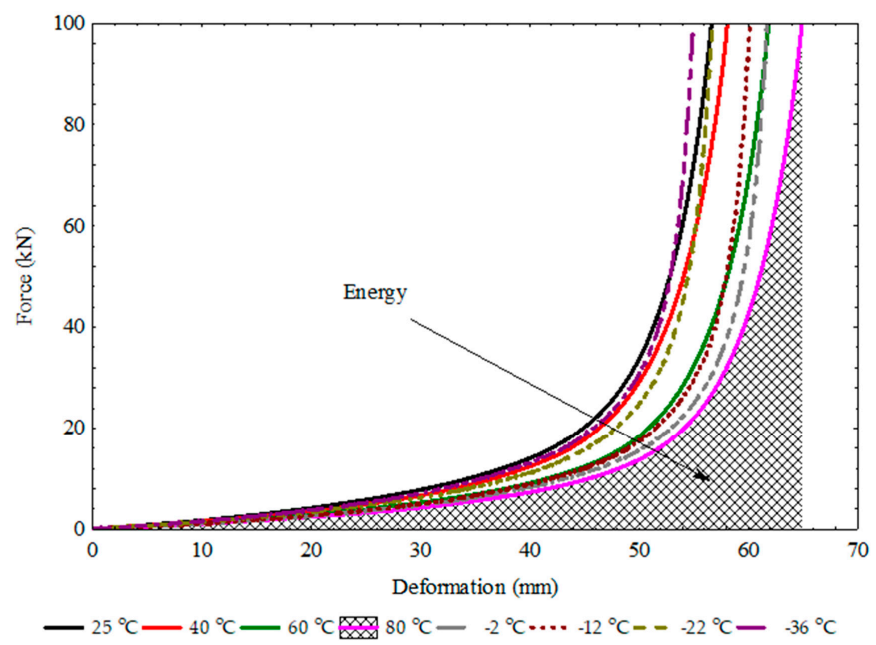

Figure 2. Force-deformation curves of the pretreated samples at different temperatures (the area under the curve is deformation energy, DE (J)). 


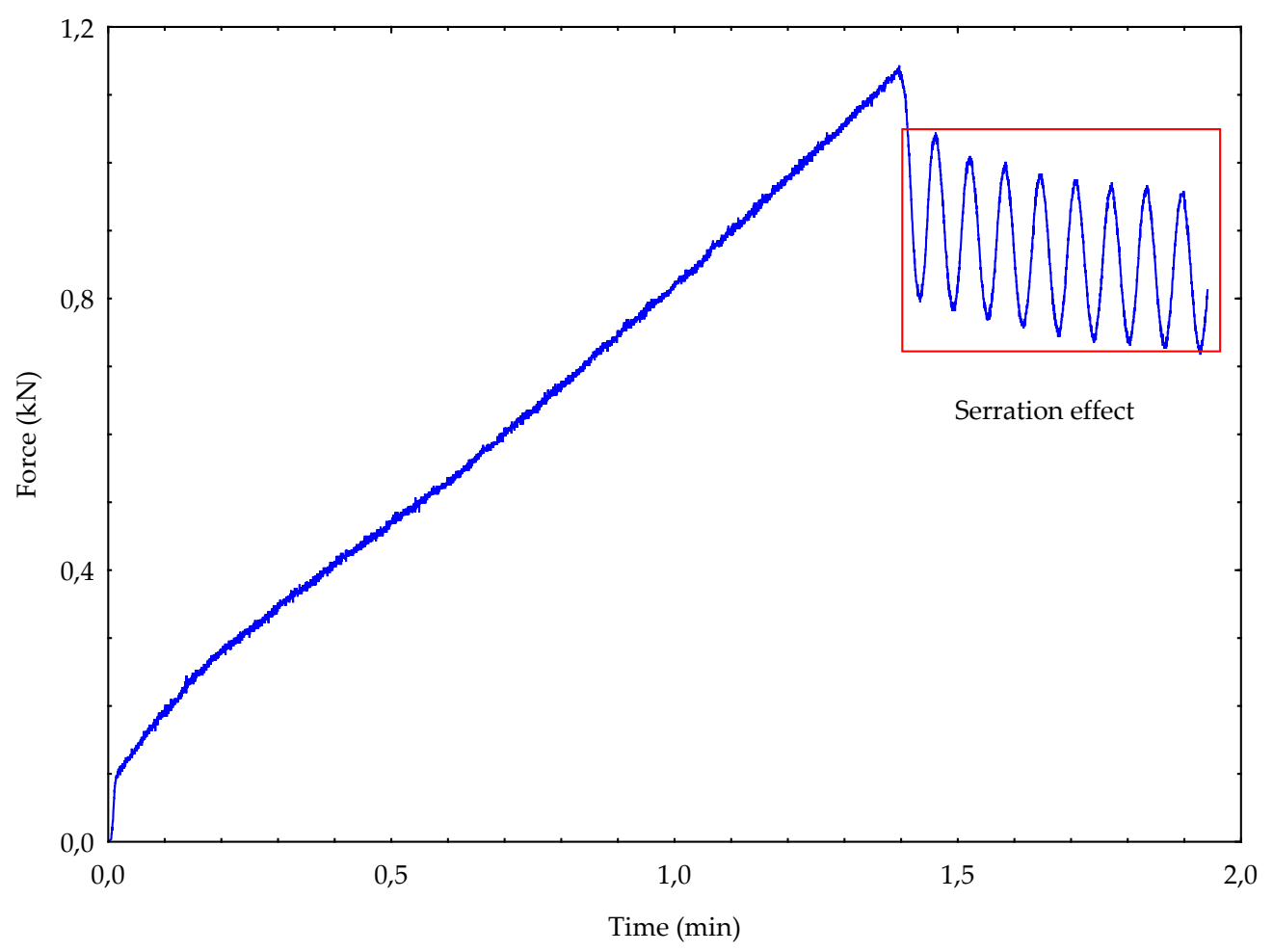

Figure 3. Force-time compression process of sunflower seeds after freezing pretreatment (samples together with the vessel diameter and plunger).

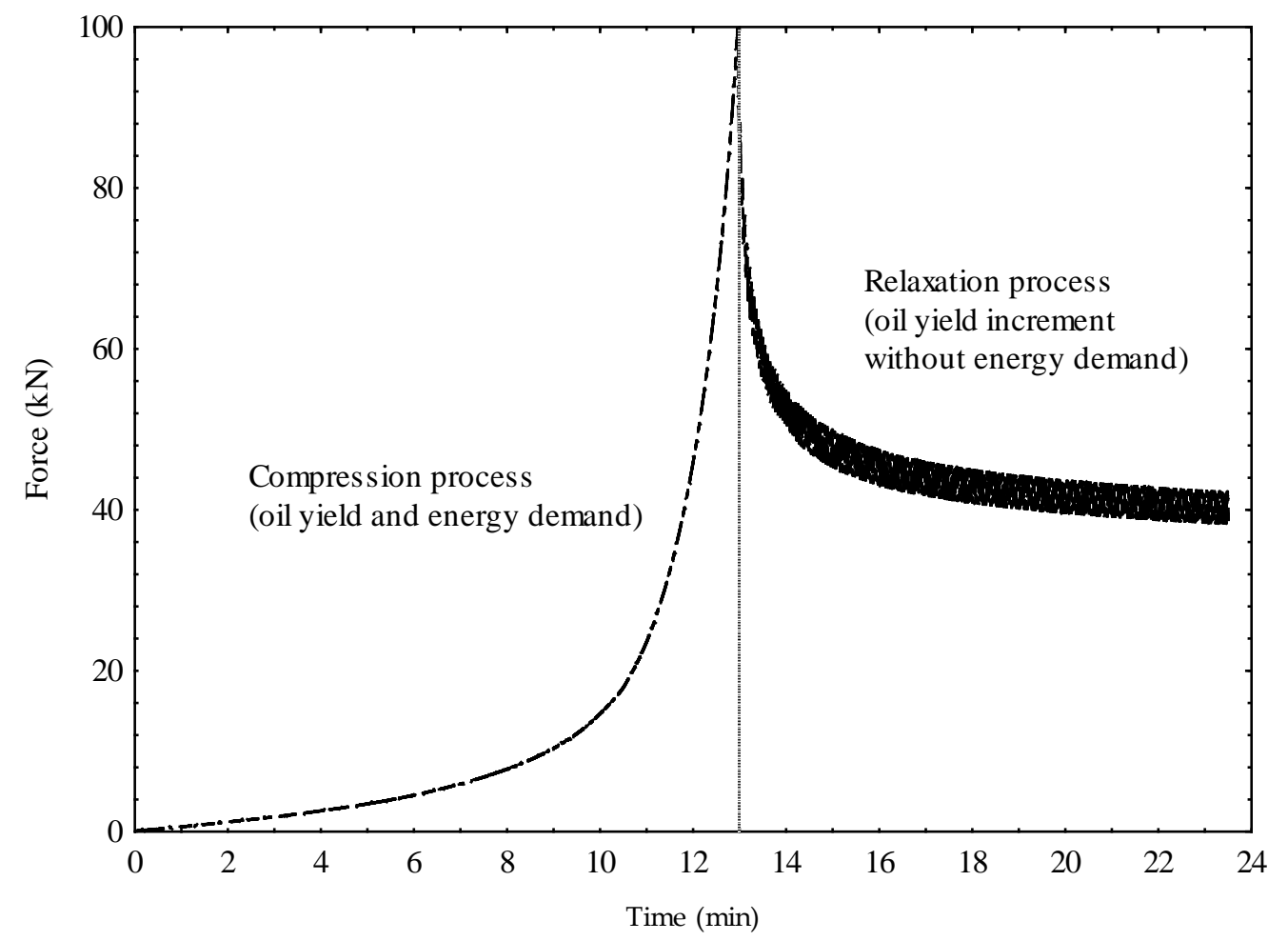

Figure 4. Compression and relaxation time curves of sunflower seeds for control at $25{ }^{\circ} \mathrm{C}$ (as a representation of the pretreatment processes). 


\subsection{Dependent Variables in Relation to Heating Temperatures}

The descriptive statistics, tests of normality, ANOVA analysis, post-hoc tests, regression and correlation of the dependent variables; deformation, DX (mm), oil yield, OY (\%), oil expression efficiency, OEE (\%), deformation energy, DE (J), energy per volume oil, EVO (kJ/L) and energy per unit volume, EUV $\left(\mathrm{kJ} / \mathrm{m}^{3}\right)$ in relation to the effect of heating temperatures are given in Tables 1-3. Based on the raw data (Table 1), deformation, oil yield and oil expression efficiency increased along with the heating temperatures. The values of deformation energy and energy per unit volume of samples showed both increasing and decreasing trends together with heating temperatures. Most importantly, energy per volume oil decreased with the increase in heating temperatures. The energy per volume oil of $22.55 \pm 0.91 \mathrm{~kJ} / \mathrm{L}$ was found at a temperature of $80^{\circ} \mathrm{C}$ compared to the control $\left(25^{\circ} \mathrm{C}\right)$ of $33.93 \pm 3.866 \mathrm{~kJ} / \mathrm{L}$. The normal distribution of the data was demonstrated by the standard deviation, standard error and the lower and upper boundaries of the $95 \%$ confidence interval of the mean (Table 1 ). This meant that the data points were relatively similar and they occurred within a small range of values with fewer outliers on the high and low ends of the data range. The ANOVA results of the dependent variables along with heating temperatures (Table 2) indicated that oil yield, oil expression efficiency and energy per volume oil were significant $(P$-value $<0.05)$ whiles the deformation, deformation energy and energy per unit volume showed non-significant $(P$-value $>0.05)$.

Table 1. Descriptive statistics of dependent variables in relation to heating temperature, $\mathrm{HT}\left({ }^{\circ} \mathrm{C}\right)$.

\begin{tabular}{|c|c|c|c|c|c|c|}
\hline \multirow{2}{*}{$\begin{array}{c}\text { Dependent } \\
\text { Variables }\end{array}$} & \multirow{2}{*}{$\begin{array}{l}\mathrm{HT} \\
\left({ }^{\circ} \mathrm{C}\right)\end{array}$} & \multirow{2}{*}{ Mean } & \multirow[b]{2}{*}{ Std. Dev. } & \multirow{2}{*}{ Std. Error } & \multicolumn{2}{|c|}{$95 \%$ Confidence Interval for Mean } \\
\hline & & & & & Lower Bound & Upper Bound \\
\hline \multirow{4}{*}{ DX (mm) } & $* 25$ & 60.66 & 3.483 & 2.011 & 52.01 & 69.32 \\
\hline & 40 & 61.54 & 2.977 & 1.719 & 54.14 & 68.93 \\
\hline & 60 & 62.84 & 1.155 & 0.667 & 59.97 & 65.71 \\
\hline & 80 & 63.86 & 1.776 & 1.025 & 59.44 & 68.26 \\
\hline \multirow{4}{*}{ OY $(\%)$} & $* 25$ & 20.74 & 1.528 & 0.882 & 16.95 & 24.54 \\
\hline & 40 & 25.26 & 1.212 & 0.700 & 22.25 & 28.27 \\
\hline & 60 & 27.40 & 0.928 & 0.536 & 25.10 & 29.71 \\
\hline & 80 & 30.95 & 0.626 & 0.361 & 29.40 & 32.51 \\
\hline \multirow{4}{*}{ OEE (\%) } & $* 25$ & 62.63 & 4.612 & 2.663 & 51.17 & 74.08 \\
\hline & 40 & 76.25 & 3.659 & 2.112 & 67.16 & 85.34 \\
\hline & 60 & 82.73 & 2.802 & 1.617 & 75.77 & 89.69 \\
\hline & 80 & 93.46 & 1.889 & 1.091 & 88.77 & 98.15 \\
\hline \multirow{4}{*}{$\mathrm{DE}(\mathrm{J})$} & $* 25$ & 821.5 & 37.11 & 21.43 & 729.3 & 913.7 \\
\hline & 40 & 821.8 & 31.87 & 18.40 & 742.7 & 901.0 \\
\hline & 60 & 818.3 & 45.50 & 26.27 & 705.2 & 9313 \\
\hline & 80 & 819.6 & 48.68 & 28.11 & 698.7 & 940.5 \\
\hline \multirow{4}{*}{$\mathrm{EVO}(\mathrm{kJ} / \mathrm{L})$} & $* 25$ & 33.93 & 3.866 & 2.232 & 24.32 & 43.53 \\
\hline & 40 & 27.79 & 2.231 & 1.288 & 22.25 & 33.33 \\
\hline & 60 & 25.50 & 2.298 & 1.327 & 19.79 & 31.21 \\
\hline & 80 & 22.55 & 0.919 & 0.531 & 20.26 & 24.83 \\
\hline \multirow{4}{*}{$\begin{array}{c}\mathrm{EUV}\left(\times 10^{2}\right. \\
\left.\mathrm{kJ} / \mathrm{m}^{3}\right)\end{array}$} & $* 25$ & 36.32 & 1.641 & 0.947 & 32.24 & 40.39 \\
\hline & 40 & 36.33 & 1.409 & 0.813 & 32.83 & 39.83 \\
\hline & 60 & 36.18 & 2.011 & 1.161 & 31.18 & 41.17 \\
\hline & 80 & 36.23 & 2.152 & 1.243 & 30.89 & 41.58 \\
\hline
\end{tabular}

* Control; HT: temperature; DX: deformation; OY: oil yield (\%); OEE: oil expression efficiency (\%); DE: deformation energy; EVO: energy per volume oil; EUV: energy per unit volume; Std. Dev and Err: Standard Deviation and Error. 
Table 2. ANOVA results of the dependent variables in relation to heating temperature, $\mathrm{HT}\left({ }^{\circ} \mathrm{C}\right)$.

\begin{tabular}{|c|c|c|c|c|c|c|c|}
\hline \multicolumn{2}{|c|}{ Dependent } & \multirow{2}{*}{$\begin{array}{l}\text { Sum of } \\
\text { Squares }\end{array}$} & \multirow{2}{*}{ df } & \multirow{2}{*}{$\begin{array}{l}\text { Mean } \\
\text { Square }\end{array}$} & \multirow{2}{*}{ F-value } & \multirow{2}{*}{ P-value } & \multirow[b]{2}{*}{$\mathbf{R}^{2}$} \\
\hline Variables & Effect & & & & & & \\
\hline \multirow{3}{*}{$\mathrm{DX}(\mathrm{mm})$} & $\mathrm{HT}\left({ }^{\circ} \mathrm{C}\right)$ & 17.78 & 3 & 5.927 & 0.930 & 0.469 & 0.259 \\
\hline & Error & 50.97 & 8 & 6.372 & & & \\
\hline & Total & 68.75 & 11 & & & & \\
\hline \multirow{3}{*}{ Oil yield (\%) } & $\mathrm{HT}\left({ }^{\circ} \mathrm{C}\right)$ & 164.0 & 3 & 54.67 & 43.268 & 0.000 & 0.942 \\
\hline & Error & 10.11 & 8 & 1.264 & & & \\
\hline & Total & 174.1 & 11 & & & & \\
\hline \multirow{3}{*}{ Oil EE (\%) } & $\mathrm{HT}\left({ }^{\circ} \mathrm{C}\right)$ & 1495 & 3 & 498.4 & 43.268 & 0.000 & 0.942 \\
\hline & Error & 92.15 & 8 & 11.52 & & & \\
\hline & Total & 1587 & 11 & & & & \\
\hline \multirow{3}{*}{ Energy $(\mathrm{J})$} & $\mathrm{HT}\left({ }^{\circ} \mathrm{C}\right)$ & 25.47 & 3 & 8.491 & 0.005 & 0.999 & 0.002 \\
\hline & Error & 13665 & 8 & 1708 & & & \\
\hline & Total & 13690 & 11 & & & & \\
\hline \multirow{3}{*}{$\mathrm{EVO}(\mathrm{kJ} / \mathrm{L})$} & $\mathrm{HT}\left({ }^{\circ} \mathrm{C}\right)$ & 209.7 & 3 & 69.91 & 10.735 & 0.004 & 0.801 \\
\hline & Error & 52.1 & 8 & 6.512 & & & \\
\hline & Total & 261.8 & 11 & & & & \\
\hline \multirow{3}{*}{$\begin{array}{c}\mathrm{EUV}\left(\times 10^{2}\right. \\
\left.\mathrm{kJ} / \mathrm{m}^{3}\right)\end{array}$} & $\mathrm{HT}\left({ }^{\circ} \mathrm{C}\right)$ & 0.05 & 3 & 0.017 & 0.005 & 0.999 & 0.002 \\
\hline & Error & 26.71 & 8 & 3.338 & & & \\
\hline & Total & 26.76 & 11 & & & & \\
\hline
\end{tabular}

Table 3. Correlation and linear regression results in relation to heating temperatures, $\mathrm{HT}\left({ }^{\circ} \mathrm{C}\right)$.

\begin{tabular}{ccccc}
\hline $\begin{array}{c}\text { Dependent } \\
\text { Variables }\end{array}$ & $\begin{array}{c}\mathbf{R} \\
\mathbf{( - )}\end{array}$ & $\begin{array}{c}\mathbf{R}^{\mathbf{2}} \\
\mathbf{( - )}\end{array}$ & $\begin{array}{c}\text { F-value } \\
\mathbf{( - )}\end{array}$ & $\begin{array}{c}\text { P-value } \\
\mathbf{( - )}\end{array}$ \\
\hline DX $(\mathrm{mm})$ & 0.508 & 0.258 & 3.477 & $>0.05$ \\
OY $(\%)$ & 0.953 & 0.908 & 99.47 & $<0.05$ \\
OEE $(\%)$ & 0.953 & 0.908 & 99.47 & $<0.05$ \\
OE $(\mathrm{J})$ & -0.031 & 0.001 & 0.011 & $>0.05$ \\
EVO $(\mathrm{kJ} / \mathrm{L})$ & -0.857 & 0.734 & 27.64 & $<0.05$ \\
EUV $\left(\times 10^{2} \mathrm{~kJ} / \mathrm{m}^{3}\right)$ & -0.031 & 0.001 & 3.011 & $>0.05$ \\
\hline
\end{tabular}

$\mathrm{R}$ is the Pearson Correlation; $\mathrm{R}^{2}$ is the coefficient of determination; Significant: F-value $>\mathrm{P}$-value or P-value $<0.05$; Non-significant: F-value $<$ P-value or P-value $>0.05$.

The correlation and linear regression results are given in Table 3. Correlation values between -0.031 and 0.953 were obtained among the dependent variables in relation to heating temperatures. Oil yield, oil expression efficiency and energy per volume oil significantly correlated $(P$-value $<0.05)$ with heating temperatures in comparison with deformation, deformation energy, and energy per unit volume, which did not significantly $(P$-value $>0.05)$ correlate with heating temperatures. The linear regression equations expressing oil expression efficiency, OEE (\%) and energy per volume oil, $E V O$ $(\mathrm{kJ} / \mathrm{L})$ dependent on heating treatment temperatures, $H T^{\circ} \mathrm{C}$ are given in equations (Equations (1) and (2)) as follows:

$$
\begin{aligned}
& O E E=51.66+0.529 \cdot H T \\
& E V O=37.34-0.193 \cdot H T
\end{aligned}
$$

The coefficients described in the equations were statistically significant $(P$-value $<0.05)$ with high coefficients of determination $\left(R^{2}\right)$ values of 0.908 and 0.734 respectively. 


\subsection{Dependent Variables in Relation to Freezing Temperatures}

The descriptive statistics, tests of normality, ANOVA analysis, post-hoc tests, regression and correlation of the dependent variables; deformation DX $(\mathrm{mm})$, oil yield OY $(\%)$, oil expression efficiency OEE (\%), deformation energy DE (J), energy per volume oil EVO $(\mathrm{kJ} / \mathrm{L})$, and energy per unit volume $\operatorname{EUV~}\left(\mathrm{kJ} / \mathrm{m}^{3}\right)$ in relation to the effect of freezing temperatures are given in Tables 4-6. Based on the raw data (Table 4), deformation, oil yield and oil expression efficiency decreased along with the freezing temperatures. The values of deformation energy and energy per unit volume of sunflower seeds showed both increasing and decreasing trends with freezing temperatures. The energy per volume oil of $26.40 \pm 0.307 \mathrm{~kJ} / \mathrm{L}$ was observed at the freezing temperature of $-2{ }^{\circ} \mathrm{C}$ compared to the control of $33.93 \pm 3.866 \mathrm{~kJ} / \mathrm{L}$. The normal distribution of the data was confirmed by the standard deviation, standard error and the lower and upper boundaries of the $95 \%$ confidence interval of the mean (Table 4). This meant that the data points were relatively similar and they occurred within a small range of values with fewer outliers on the high and low ends of the data range. The ANOVA results of the dependent variables along with freezing temperatures (Table 5) were significant $(P$-value $<0.05)$ except energy and energy per unit volume of sunflower seeds which indicated non-significant $(P$-value $>0.05)$.

Table 4. Descriptive statistics of dependent variables in relation to freezing temperature, $\mathrm{FT}\left({ }^{\circ} \mathrm{C}\right)$.

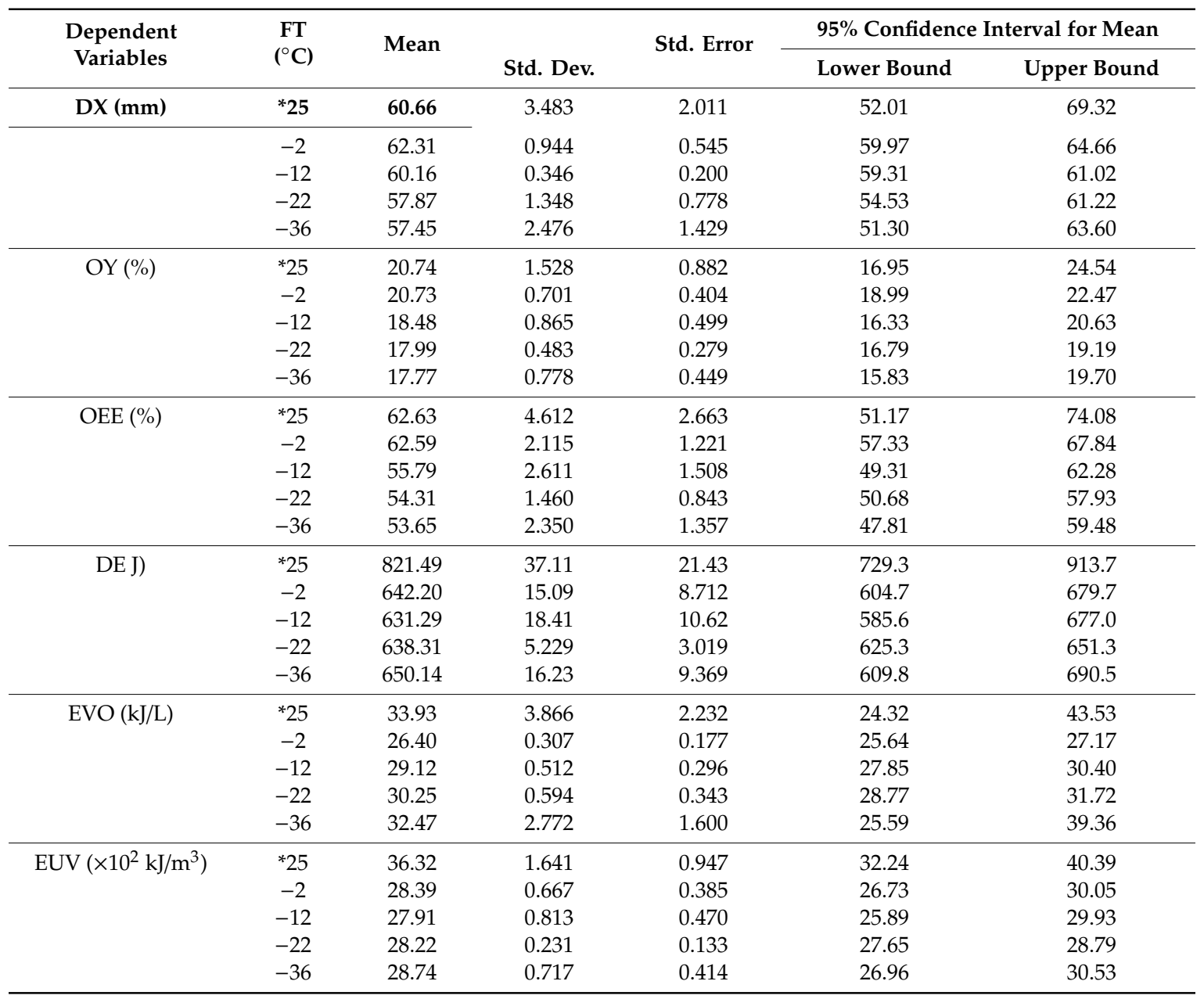

* Control; FT: DX: deformation; OY: oil yield (\%); OEE: oil expression efficiency (\%); DE: deformation energy; EVO: energy per volume oil; EUV: energy per unit volume; Std. Dev and Err: Standard Deviation and Error. 
Table 5. ANOVA results of the dependent variables in relation to freezing temperature, FT $\left({ }^{\circ} \mathrm{C}\right)$.

\begin{tabular}{|c|c|c|c|c|c|c|c|}
\hline \multicolumn{2}{|c|}{ Dependent } & \multirow{2}{*}{$\begin{array}{l}\text { Sum of } \\
\text { Squares }\end{array}$} & \multirow{2}{*}{ df } & \multirow{2}{*}{$\begin{array}{l}\text { Mean } \\
\text { Square }\end{array}$} & \multirow{2}{*}{ F-value } & \multirow{2}{*}{ P-value } & \multirow[b]{2}{*}{$\mathbf{R}^{2}$} \\
\hline Variable & Effect & & & & & & \\
\hline \multirow{3}{*}{ DX (mm) } & $\mathrm{FT}\left({ }^{\circ} \mathrm{C}\right)$ & 45.54 & 3 & 15.18 & 6.780 & 0.014 & 0.718 \\
\hline & Error & 17.91 & 8 & 2.239 & & & \\
\hline & Total & 63.45 & 11 & & & & \\
\hline \multirow{3}{*}{$\begin{array}{l}\text { Oil yield } \\
\qquad(\%)\end{array}$} & $\mathrm{FT}\left({ }^{\circ} \mathrm{C}\right)$ & 16.62 & 3 & 5.540 & 10.66 & 0.004 & 0.811 \\
\hline & Error & 4.157 & 8 & 0.520 & & & \\
\hline & Total & 20.75 & 11 & & & & \\
\hline \multirow{3}{*}{ Oil EE (\%) } & $\mathrm{FT}\left({ }^{\circ} \mathrm{C}\right)$ & 151.5 & 3 & 50.51 & 10.66 & 0.004 & 0.811 \\
\hline & Error & 37.89 & 8 & 4.737 & & & \\
\hline & Total & 189.4 & 11 & & & & \\
\hline \multirow{3}{*}{ Energy (J) } & $\mathrm{FT}\left({ }^{\circ} \mathrm{C}\right)$ & 556.2 & 3 & 185.4 & 0.865 & 0.498 & 0.245 \\
\hline & Error & 1713.7 & 8 & 214.2 & & & \\
\hline & Total & 2269.9 & 11 & & & & \\
\hline \multirow{3}{*}{$\mathrm{EVO}(\mathrm{kJ} / \mathrm{L})$} & $\mathrm{FT}\left({ }^{\circ} \mathrm{C}\right)$ & 57.35 & 3 & 19.12 & 9.112 & 0.006 & 0.774 \\
\hline & Error & 16.79 & 8 & 2.098 & & & \\
\hline & Total & 74.14 & 11 & & & & \\
\hline \multirow{3}{*}{$\begin{array}{c}\mathrm{EUV}\left(\times 10^{2}\right. \\
\left.\mathrm{kJ} / \mathrm{m}^{3}\right)\end{array}$} & $\mathrm{FT}\left({ }^{\circ} \mathrm{C}\right)$ & 1.087 & 3 & 0.362 & 0.865 & 0.498 & 0.245 \\
\hline & Error & 3.349 & 8 & 0.419 & & & \\
\hline & Total & 4.437 & 11 & & & & \\
\hline
\end{tabular}

Table 6. Correlation and linear regression results in relation to freezing temperature, $\mathrm{FT}\left({ }^{\circ} \mathrm{C}\right)$.

\begin{tabular}{ccccc}
\hline $\begin{array}{c}\text { Dependent } \\
\text { Variables }\end{array}$ & $\begin{array}{c}\mathbf{R} \\
(-)\end{array}$ & $\begin{array}{c}\mathbf{R}^{\mathbf{2}} \\
\mathbf{( - )}\end{array}$ & $\begin{array}{c}\text { F-value } \\
\mathbf{( - )}\end{array}$ & $\begin{array}{c}\text { P-value } \\
\mathbf{( - )}\end{array}$ \\
\hline DX $(\mathbf{m m})$ & 0.799 & 0.683 & 17.615 & $<0.05$ \\
OY $(\%)$ & 0.768 & 0.5898 & 14.351 & $<0.05$ \\
OEE $(\%)$ & 0.768 & 0.5898 & 14.351 & $<0.05$ \\
OE $(\mathrm{J})$ & -0.279 & 0.078 & 0.843 & $>0.05$ \\
EVO $(\mathrm{kJ} / \mathrm{L})$ & -0.867 & 0.751 & 30.197 & $<0.05$ \\
EUV $\left(\times 10^{2} \mathrm{~kJ} / \mathrm{m}^{3}\right)$ & -0.279 & 0.078 & 0.843 & $>0.05$ \\
\hline
\end{tabular}

Significant: F-value $>\mathrm{P}$-value or P-value $<0.05$; Non-significant: F-value $<\mathrm{P}$-value or P-value $>0.05$; $\mathrm{R}$ is the correlation coefficient; $R^{2}$ is the coefficient of determination.

The correlation and linear regression results are given in Table 6. Correlation values between 0.279 and 0.799 were obtained among the dependent variables along with freezing temperatures. The correlation among deformation, oil yield, oil expression efficiency and energy per unit volume against freezing temperature was significant $(P$-value $<0.05)$. The correlation between energy and energy per volume of oil versus freezing temperatures was non-significant $(P$-value $>0.05)$. The linear regression equations expressing oil expression efficiency, OEE (\%), and energy per volume oil, EVO $(\mathrm{kJ} / \mathrm{L})$, dependent on freezing temperature, $F T^{\circ} \mathrm{C}$, are given in Equations (3) and (4) as follows:

$$
\begin{aligned}
& O E E=60.95+0.243 \cdot F T \\
& E V O=26.48-0.171 \cdot F T
\end{aligned}
$$

The coefficients described in the equations were statistically significant $(P$-value $<0.05)$ with coefficients of determination $\left(R^{2}\right)$ values of 0.589 and 0.751 respectively. 


\subsection{Evaluation of Heating and Freezing Temperatures, $T P\left({ }^{\circ} \mathrm{C}\right)$}

The scatterplots of oil expression efficiency, OEE (\%) and energy per volume oil, $E V O(\mathrm{~kJ} / \mathrm{L})$ are displayed in Figures 5 and 6. It can be seen clearly that, increasing temperatures from $-36{ }^{\circ} \mathrm{C}$ to $80^{\circ} \mathrm{C}$ increased the oil expression efficiency with the correlation value of 0.953 whiles energy per volume oil decreased with the correlation value of -0.611 . The heating temperature of $80^{\circ} \mathrm{C}$ produced the highest oil expression efficiency of $93.46 \pm 1.889 \%$ as well as the lowest energy per volume oil of $22.55 \pm 0.919 \mathrm{~kJ} / \mathrm{L}$ suggesting the most energy-efficient temperature for obtaining the maximum oil. In comparison with literature [38], indicated that heating sunflower kernels before hexane and aqueous extraction process improved oil recovery efficiency. [39] also reported the highest oil yield of $47.06 \%$ of jatropha kernels at a drying temperature of $80^{\circ} \mathrm{C}$. The linear regression equations expressing oil expression efficiency, OEE (\%), and energy per volume oil $(\mathrm{kJ} / \mathrm{L})$, dependent on the combined temperature effects (heating and freezing), $T P\left({ }^{\circ} \mathrm{C}\right)$, are given in Equations (5) and (6) as follows:

$$
\begin{aligned}
& O E E=61.92+0.346 \cdot T P \\
& E V O=29.52-0.061 \cdot T P
\end{aligned}
$$

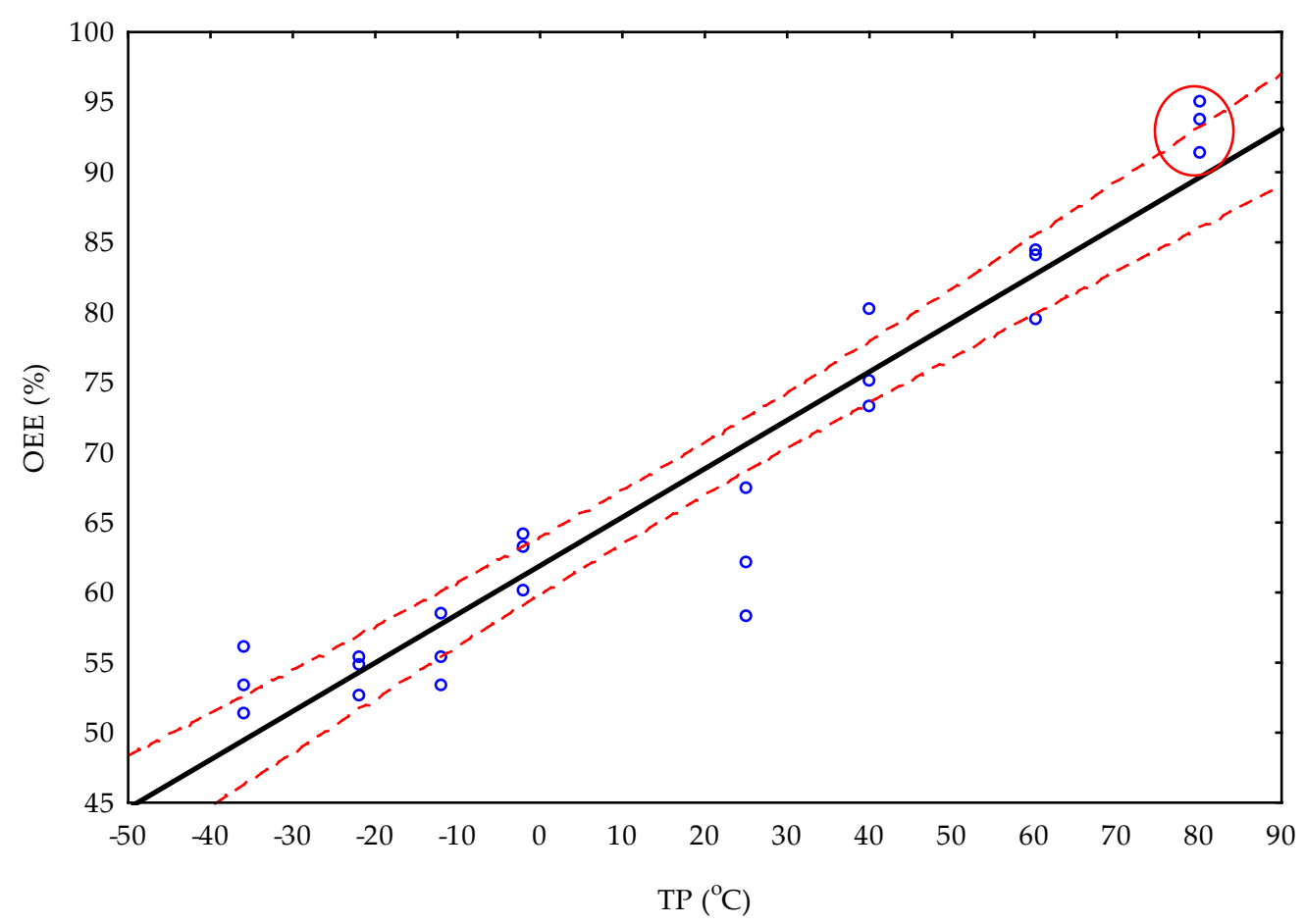

Figure 5. Scatterplot: $\mathrm{OEE}(\%)$ versus $\mathrm{TP}\left({ }^{\circ} \mathrm{C}\right)$ based on $95 \%$ confidence interval; optimum temperature is circled.

The coefficients described in the equations were statistically significant $(P$-value $<0.05)$ with coefficients of determination $\left(R^{2}\right)$ values of 0.908 and 0.373 respectively. 


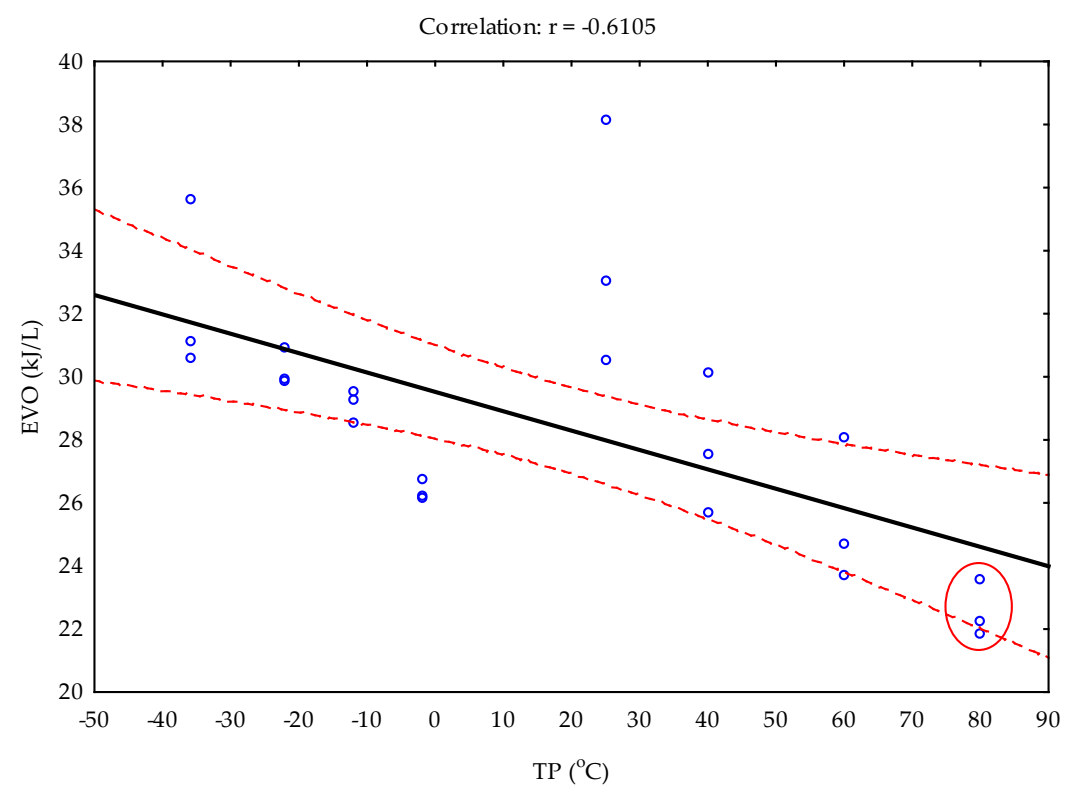

Figure 6. Scatterplot: $\mathrm{EVO}(\mathrm{kJ} / \mathrm{L})$ versus $\mathrm{TP}\left({ }^{\circ} \mathrm{C}\right)$ based on $95 \%$ confidence interval; optimum temperature is circled.

\subsection{Peroxide Value and Free Fatty Acid}

The descriptive statistics of peroxide value and free fatty acid of sunflower oil along with heating and freezing temperatures are given in Table 7. Based on the Shapiro-Wilk test [79], whereas the heating data were not normally distributed, the freezing data were normally distributed. However, peroxide and free fatty acid values showed both increasing and decreasing trends with heating and freezing temperatures respectively. The linear regression equations expressing peroxide value, $P V$ $(\mu \mathrm{g} / \mathrm{g}$ of active oxygen) and free fatty acid, FFA $(\mathrm{mg} \mathrm{KOH} / \mathrm{g})$ dependent on combined temperatures, TP $\left({ }^{\circ} \mathrm{C}\right)$ are given in Equations (7) and (8) as follows:

$$
\begin{gathered}
P V=52.90+0.245 \cdot T P \\
F F A=0.995+0.003 \cdot T P
\end{gathered}
$$

\begin{tabular}{|c|c|c|c|c|c|c|}
\hline \multirow{2}{*}{$\begin{array}{l}\text { Dependent } \\
\text { Variables }\end{array}$} & \multirow{2}{*}{$\begin{array}{l}\text { TP } \\
\left({ }^{\circ} \mathrm{C}\right)\end{array}$} & \multirow{2}{*}{ Mean } & \multirow[b]{2}{*}{ Std. Dev } & \multirow{2}{*}{ Std. Err } & \multicolumn{2}{|c|}{ 95\% Confidence Interval for Mean } \\
\hline & & & & & $\begin{array}{l}\text { Lower } \\
\text { Bound }\end{array}$ & Upper Bound \\
\hline \multirow{8}{*}{$\begin{array}{c}\text { PV ( } \mu \mathrm{g} / \mathrm{g} \text { of active } \\
\text { oxygen })\end{array}$} & -36 & 36.79 & 1.015 & 0.718 & 27.67 & 45.91 \\
\hline & -22 & 51.55 & 0.010 & 0.007 & 51.46 & 51.64 \\
\hline & -12 & 76.03 & 3.122 & 2.207 & 47.98 & 104.07 \\
\hline & -2 & 31.32 & 0.578 & 0.409 & 26.12 & 36.51 \\
\hline & $* 25$ & 51.22 & 0.778 & 0.550 & 44.23 & 58.20 \\
\hline & 40 & 73.88 & 1.749 & 1.236 & 58.17 & 89.59 \\
\hline & 60 & 54.97 & 0.016 & 0.012 & 54.82 & 55.11 \\
\hline & 80 & 80.06 & 1.371 & 0.969 & 67.75 & 92.38 \\
\hline \multirow{8}{*}{ FFA (mg KOH/g) } & -36 & 0.886 & 0.021 & 0.015 & 0.698 & 1.074 \\
\hline & -22 & 0.953 & 0.102 & 0.072 & 0.039 & 1.867 \\
\hline & -12 & 0.909 & 0.000 & 0.000 & 0.908 & 0.909 \\
\hline & -2 & 0.890 & 0.026 & 0.018 & 0.660 & 1.120 \\
\hline & $* 25$ & 1.266 & 0.113 & 0.080 & 0.253 & 2.279 \\
\hline & 40 & 1.186 & 0.102 & 0.072 & 0.273 & 2.100 \\
\hline & 60 & 1.082 & 0.017 & 0.012 & 0.926 & 1.239 \\
\hline & 80 & 1.135 & 0.008 & 0.006 & 1.062 & 1.208 \\
\hline
\end{tabular}

Table 7. Descriptive statistics of the effect of heating and freezing temperatures, $\operatorname{TP}\left({ }^{\circ} \mathrm{C}\right)$.

Std. Dev and Err: Standard Deviation and Error. 
The coefficients described in the equations were statistically significant $(P$-value $<0.05)$ with coefficients of determination $\left(R^{2}\right)$ values of 0.475 and 0.309 respectively. Peroxide value measures the degree of either the occurrence of peroxidation or adulteration and could be used to evaluate the quality and stability of oils during storage. Low peroxide value of oils indicates that the oils are more saturated and thus reflects the high quality of the oil $[78,81,82]$. The presence of a high number of fatty acids in vegetable oil as well as multiple possibilities of their combination with glycerol, make vegetable oils very complex mixtures with significantly different structures and properties $[58,83]$. High levels of free fatty acid in crude vegetable oils might be attributed to impurities that could cause hydrolysis of the ester linkage [84].

\subsection{Spectral Profiles of Sunflower Oil Samples}

The spectral profiles of sunflower oil samples are illustrated in Figures 7 and 8. The absorption peaks of the oil samples obtained from heating and freezing treatments were observed at wavelengths between 350 and $525 \mathrm{~nm}$. Increased heating temperatures increased the UV absorption rate. Oil sample at $80^{\circ} \mathrm{C}$ showed very high absorption whiles $40^{\circ} \mathrm{C}$ recorded the lowest. On the other hand, the absorption rate decreased at temperatures from -22 to $-2{ }^{\circ} \mathrm{C}$. However, $-36{ }^{\circ} \mathrm{C}$ showed very low absorption rate compared to $-2{ }^{\circ} \mathrm{C}$. The refraction of the absorption profiles thus represents the UV transmittance profiles. Increasing heating temperatures recorded transmittance values of the oil samples between $105.5 \%$ and $52.20 \%$. The transmittance values of the oil samples with freezing temperatures were between $98.30 \%$ and $72.83 \%$. The profiles peaks could be attributed to phenolic conjugated/unconjugated structures and alkaline compounds in the oil samples. In the literature, [77] reported the spectral curves of biodiesel samples with absorbance maxima between 232 and $280 \mathrm{~nm}$. The authors stated that the maximum absorbance at 270 and $280 \mathrm{~nm}$ were typical of short carbon chain aliphatic compounds with carbonyl groups as those found in free fatty acids, alkyl esters, aldehydes and ketones. The maximum absorbance at $232 \mathrm{~nm}$ was due to the conjugated bond of the polyunsaturated long carbon chain and carbonyl groups [77]. The absorption and transmittance rates of 8 edible oils at wavelengths between 200 and $400 \mathrm{~nm}$ have been also reported [85]. The authors highlighted that cod liver oil and coconut oil showed a poor rate of absorption from -2 to 0 . Groundnut oil showed poor absorption of zero. Mustard and castor oils showed slight absorption of 0 to 0.2 . Sesame oil showed an absorption of 0 to 0.25 . Neem oil showed an absorption of 0.1 to 0.4 . Chicken oil showed a very high range of absorption of 0.6 to 0.75 . The authors explained that the UV visible absorption corresponds to the excitation of outer electrons, and its radiation in organic molecules is restricted to certain functional groups (chromophores) that contain valence electrons of low excitation energy. According to Bee's law, if the absorption is stronger, the value of absorptivity will be also stronger. Moreover, the transmission rates of the oils were between $60 \%$ and $100 \%$. The lower transmission of UV rays of edible oils, according to [85], can be used as a skin softener protection against UV rays. 


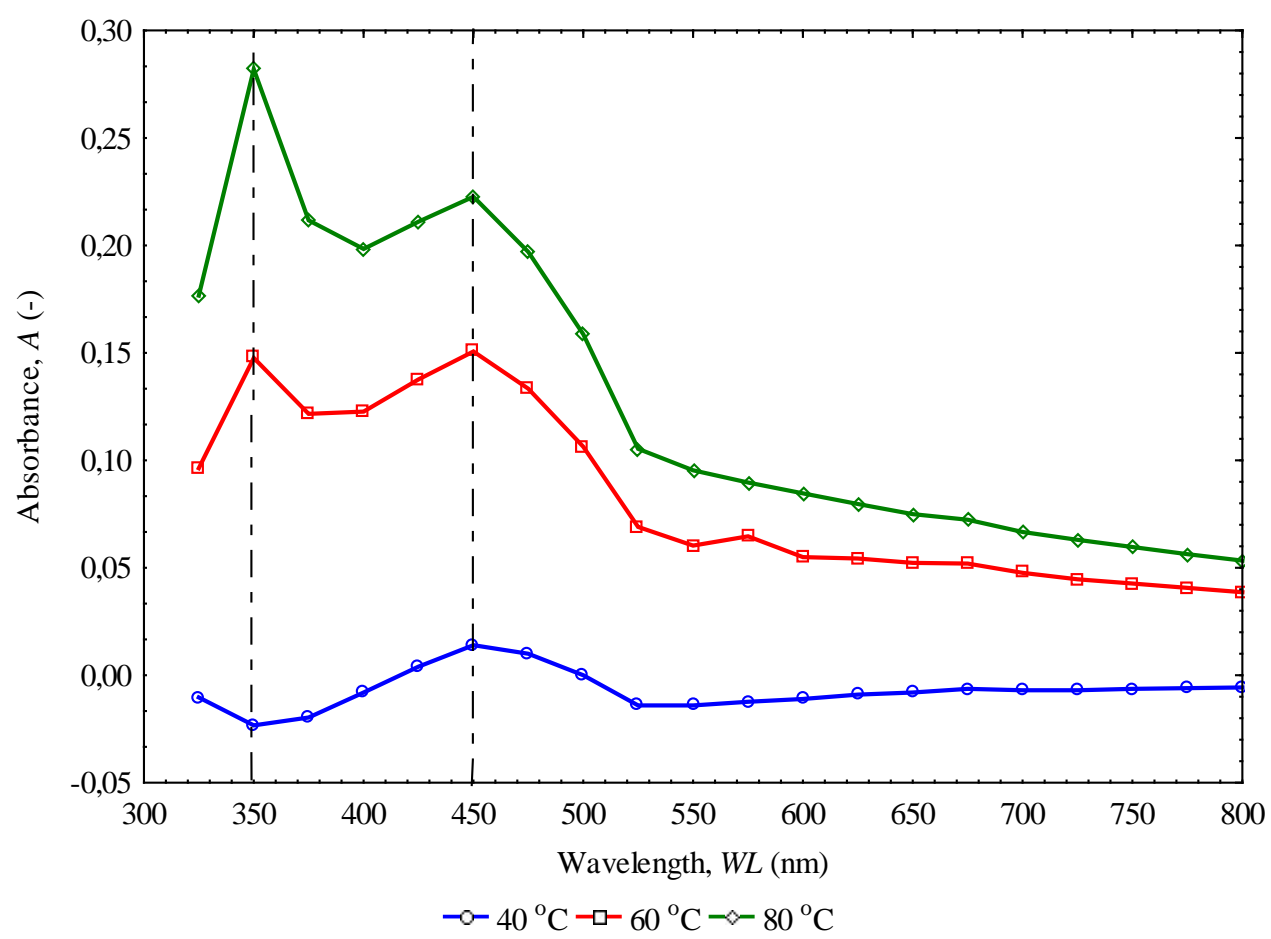

Figure 7. UV-VIS absorption spectra of sunflower oil under heating temperatures.

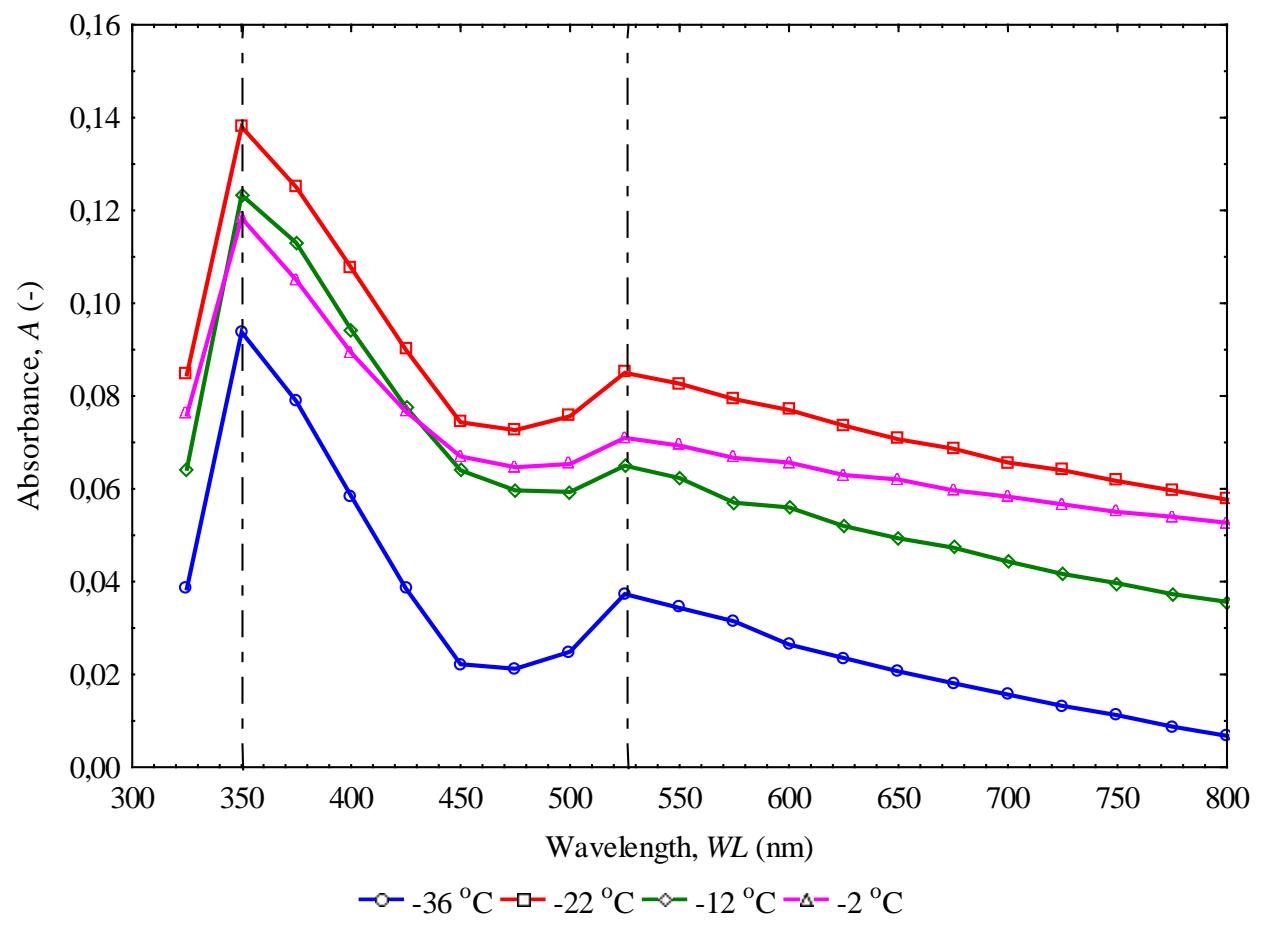

Figure 8. UV-VIS absorption spectra of sunflower oil under freezing temperatures.

\subsection{Explanation of Supplementary Materials}

For the effect of heating temperatures on dependent variables as described in (Section 3.2), the Shapiro-Wilk's test (Supplementary Table S1) significantly $(P$-value $>0.05)$ confirmed the normal distribution of the data with high values of coefficient of determination $\left(R^{2}\right)[75,86]$. However, the mean values of the oil expression efficiency and energy per volume oil were of particular interest, hence they were further compared based on Tukey HSD and Duncan post-hoc tests $(\alpha=0.05)$ (Supplementary Tables S2 and S3). The results showed that the mean values of oil expression efficiency based on Duncan 
test in relation to the heating temperatures were significantly different compared to the Tukey HSD test. The mean values of energy per volume oil at $80^{\circ} \mathrm{C}$ and $60^{\circ} \mathrm{C}$ were not significantly different from each other as well as $60^{\circ} \mathrm{C}$ and $40^{\circ} \mathrm{C}$ based on the Duncan test. The control $\left(25^{\circ} \mathrm{C}\right.$; without heating/freezing) was also significantly further apart from the heating temperatures. However, based on Tukey HSD test, the control and heating temperature at $40{ }^{\circ} \mathrm{C}$ were not significantly different. The Shapiro-Wilk's test of the freezing data (Section 3.3) (Supplementary Table S4) significantly $(P$-value $>0.05)$ described the normal distribution of the data with high values of coefficient of determination $\left(R^{2}\right)[75,86]$. The significance of the results was further evaluated based on Tukey HSD and Duncan tests (Supplementary Tables S5 and S6). The outcome showed that the mean values of oil expression efficiency (\%) at $-36{ }^{\circ} \mathrm{C}$, $-22{ }^{\circ} \mathrm{C}$ and $-12{ }^{\circ} \mathrm{C}$ were not significantly different from each other; hence they belonged to the same subset. Similarly, the control $\left(25^{\circ} \mathrm{C}\right)$ and $-2\left({ }^{\circ} \mathrm{C}\right)$ mean values were grouped into a different subset and they were not significantly different from each other. Both Tukey HSD and Duncan tests showed almost the same effect. On the other hand, energy per volume oil (kJ/L) based on Tukey HSD test grouped the means into two subsets compared to the Duncan test which grouped the means into three subsets. For instance, based on Tukey HSD test, the mean values at $-36{ }^{\circ} \mathrm{C},-22{ }^{\circ} \mathrm{C}$, and $-12{ }^{\circ} \mathrm{C}$ were not significantly different from each other. In like manner, the control $\left(25^{\circ} \mathrm{C}\right)$ and $-2{ }^{\circ} \mathrm{C}$ mean values were not significantly different. The mean values at $-22{ }^{\circ} \mathrm{C},-12{ }^{\circ} \mathrm{C},-2{ }^{\circ} \mathrm{C}$ and control $\left(25^{\circ} \mathrm{C}\right)$ were grouped into the same subset, meaning they were not significantly different. The box plots of oil yield, OY $(\%)$, oil expression efficiency, OEE (\%), deformation energy, $D E(\mathrm{~J})$, energy per volume oil, $E V O$ $(\mathrm{kJ} / \mathrm{L})$, and energy per unit volume of samples, EUV $\left(\times 10^{2} \mathrm{~kJ} / \mathrm{m}^{3}\right)$, grouped by temperature, TP $\left({ }^{\circ} \mathrm{C}\right)$, are also illustrated in Supplementary Figures S1 and S2. These plots clearly indicated the combined effects of heating and freezing temperatures on the dependent variables (Section 3.4). The peroxide value (Section 3.5) based on the ANOVA results (Supplementary Tables S7 and S8) was significant $(P$-value $<0.05)$ in connection with heating and freezing temperatures. On the other hand, free fatty acid indicated non-significant $(P$-value $>0.05)$ in both pretreatment processes. The significance of the peroxide value was further assessed by the Tukey HSD and Duncan tests (Supplementary Table S9). The Tukey HSD test grouped the means into four subsets compared to the Duncan test which grouped them into six subsets. Based on the Duncan test, for instance, the mean values at $80{ }^{\circ} \mathrm{C}, 60{ }^{\circ} \mathrm{C},-36{ }^{\circ} \mathrm{C}$, and $-2{ }^{\circ} \mathrm{C}$ were significantly different from each other; hence, they belonged to different subsets in comparison with the other mean values at $25{ }^{\circ} \mathrm{C}$ and $-22{ }^{\circ} \mathrm{C}$ as well as $60{ }^{\circ} \mathrm{C}$ and $-12{ }^{\circ} \mathrm{C}$, which were grouped into the same subset respectively. The correlation between peroxide value and heating temperature was 0.598 whereas that of free fatty acid and heating temperature was -0.622 . However, the results were non-significant $(P$-value $>0.05)$ similar to the regression results (Supplementary Tables S10 and S11). Additionally, the combined effects of heating and freezing temperatures, TP $\left({ }^{\circ} \mathrm{C}\right)$ significantly increased both the peroxide value and free fatty acid with the correlation values of 0.556 and 0.689 (Supplementary Figures S3 and S4).

\section{Conclusions}

The force-deformation curve, relaxation force-time curve, oil yield, oil expression efficiency, deformation energy, energy per volume oil, energy per unit volume of material, peroxide value, free fatty acid and UV absorption, and transmittance of sunflower seeds and oil were studied under linear compression loading. The increase in heating temperatures increased the area under the force-deformation curve whiles the decrease in freezing temperatures decreased the area under the curve representing the deformation energy. The freezing pretreatment of the sunflower seeds together with the vessel diameter and plunger before compression showed serration/undulation effect on the force-deformation curve where there was no oil leakage. Heating of the sunflower seeds at $80{ }^{\circ} \mathrm{C}$ coupled with the vessel diameter and plunger for $30 \mathrm{~min}$ and relaxation process for almost $12 \mathrm{~min}$ increased the oil expression efficiency by $25 \%$. The heating combinations at $80{ }^{\circ} \mathrm{C}$ produced the highest oil expression efficiency of $93.46 \pm 1.889 \%$ as well as the lowest energy per volume oil of $22.55 \pm 0.919$ $\mathrm{kJ} / \mathrm{L}$ suggesting the most energy-efficient temperature for obtaining the maximum oil. The freezing 
combinations and relaxation process did not increase oil expression efficiency. However, the energy per volume oil of $26.40 \pm 0.307 \mathrm{~kJ} / \mathrm{L}$ was observed at the temperature of $-2{ }^{\circ} \mathrm{C}$ compared to the control of $33.93 \pm 3.866 \mathrm{~kJ} / \mathrm{L}$. Increasing temperatures from $-36^{\circ} \mathrm{C}$ to $80^{\circ} \mathrm{C}$ increased the oil expression efficiency with the correlation value of 0.953 while energy per volume oil decreased with the correlation value of -0.611 . The combined effects of heating and freezing temperatures significantly increased both the peroxide value and free fatty acid with the correlation values of 0.556 and 0.689 . The linear regression equations expressing oil expression efficiency, energy per volume oil, peroxide value and free fatty acid, dependent on heating and freezing temperatures, were described with coefficients of determination $\left(\mathrm{R}^{2}\right)$ values of 0.908 and 0.373 respectively. The oil sample at $80{ }^{\circ} \mathrm{C}$ showed very high absorption whereas $40^{\circ} \mathrm{C}$ recorded the lowest. The absorption peaks of the oil samples from heating and freezing temperatures were observed at wavelengths between 350 and $525 \mathrm{~nm}$. The refraction of the absorption profiles thus represents the UV transmittance profiles. The profiles peaks could be attributed to phenolic conjugated/unconjugated structures and alkaline compounds in the oil samples. The study is part of the continuing research on linear compression modeling of all processing factors, where the results are intended to be applied to the non-linear process to improve the oil extraction process. Therefore, this intention requires a further extension of the present study by taking into account varying vessel diameters and pressing heights of the sunflower seeds at a maximum compression force and speed without the serration effect on the force-deformation curve at temperatures of $80{ }^{\circ} \mathrm{C}$ and $-2{ }^{\circ} \mathrm{C}$. Finally, the data would be used to predict the pressure and energy requirements of sunflower oil extraction along the pressing chambers of the mechanical screw press based on the tangent curve model and screw configuration parameters $[67,68]$ to fully understand the effects of heating and freezing pretreatment processes on oil production and quality from oil-bearing crops.

Supplementary Materials: The following are available online at http://www.mdpi.com/2227-9717/8/4/411/s1, Figure S1: Box plot of OY (\%) and OEE $(\%)$ grouped by TP $\left({ }^{\circ} \mathrm{C}\right)$, Figure S2: Box plot of multiple variables grouped by temperature $\left({ }^{\circ} \mathrm{C}\right)$, Figure S3: Scatterplot: PV ( $\mu \mathrm{g} / \mathrm{g}$ of active oxygen) versus $\mathrm{TP}\left({ }^{\circ} \mathrm{C}\right)$ based on $95 \%$ confidence interval, and Figure S4: Scatterplot: FFA (mg KOH/g) versus TP $\left({ }^{\circ} \mathrm{C}\right)$ based on $95 \%$ confidence interval, Table S1: Tests of normality of dependent variables in relation to heating temperature, HT $\left({ }^{\circ} \mathrm{C}\right)$, Table S2: Post-hoc tests of OEE ( $\%)$ based on Tukey HSD and Duncan $(\alpha=0.05)$, Table S3: Post-hoc tests of EVO $(\mathrm{kJ} / \mathrm{L})$ based on Tukey HSD and Duncan $(\alpha=0.05)$, Table S4: Tests of normality of dependent variables in relation to freezing temperature, FT $\left({ }^{\circ} \mathrm{C}\right)$, Table S5: Post-hoc tests of OEE (\%) based on Tukey HSD and Duncan $(\alpha=0.05)$, Table S6: Post-hoc tests of EVO $(\mathrm{kJ} / \mathrm{L})$ based on Tukey HSD and Duncan $(\alpha=0.05)$, Table S7: ANOVA results in relation to heating temperature, $\mathrm{HT}\left({ }^{\circ} \mathrm{C}\right)$, Table S8: ANOVA results in relation to heating temperature, FT $\left({ }^{\circ} \mathrm{C}\right)$, Table S9: Post-hoc tests of PV $(\mathrm{mg} \mathrm{KOH} / \mathrm{g})$ based on Tukey HSD and Duncan $(\alpha=0.05)$, Table S10: Correlation linear regression results of the effect of heating temperature and Table S11: Correlation and linear regression results of the effect of freezing temperature.

Author Contributions: Conceptualization, G.A.K.G.; A.K. and D.H.; Funding acquisition, D.H.; Methodology, G.A.K.G.; A.K.; P.H. and A.F.; data curation, K.Ç.S.; P.H. and A.F.; Writing-original draft, G.A.K.G.; A.K. and K.Ç.S.; Writing-review and editing, G.A.K.G.; A.K., K.Ç.S. and D.H. All authors have read and agreed to the published version of the manuscript.

Funding: The research was funded by EU, Managing Authority of the Czech Operational Programme Research, Development and Education through the project "supporting the development of international mobility of research staff at CULS Prague", Grant Number: CZ.02.2.69/0.0/0.0/16_027/0008366. The authors would like to thank the funding providers for financial support.

Conflicts of Interest: The authors declare no conflict of interest.

\section{References}

1. Konuskan, D.B.; Arslan, M.; Oksuz, A. Physiochemical properties of cold pressed sunflower, peanut, rapeseed, mustard and olive oils grown in the Eastern Mediterranean region. Saudi J. Biol. Sci. 2019, 26, 340-344. [CrossRef]

2. USDA. Oilseeds: World Markets and Trade; USDA: Washington, DC, USA, 2018.

3. Martinez-Force, E.; Dunford, N.T.; Salas, J.J. Sunflower: Chemistry, Production, Processing, and Utilization; Elsevier: Amsterdam, The Netherlands, 2015. 
4. Friedman, M.; Brandon, D.L. Nutritional and health benefits of soy proteins. J. Agric. Food Chem. 2001, 49, 1069-1086. [CrossRef]

5. Karefyllakis, D.; Van der Goot, A.J.; Nikiforidis, C.V. Multicomponent emulsifiers from sunflower seeds. Curr. Opin. Food Sci. 2019, 29, 35-41. [CrossRef]

6. Izli, N.; Unal, H.; Sincik, M. Physical and mechanical properties of rapeseed at different moiture content. Int. Agrophys. 2009, 23, 137-145.

7. Pereyra-Irujo, G.A.; Izquierdo, N.G.; Covi, M.; Nolasco, S.M.; Quiroz, F.; Aguirrezabal, L.A.N. Variability in sunflower oil quality for biodiesel production: A simulation study. Biomass Bioenergy 2009, 33, 459-468. [CrossRef]

8. Gonzalez-Perez, S.; Vereijken, J.M. Sunflower proteins: Overview of their physiochemical, structural and functional properties. J. Sci. Food Agric. 2007, 87, 2173-2191. [CrossRef]

9. Gupta, R.K.; Das, S.K. Facture resistance of sunflower seed and kernel to compressive loading. J. Food Eng. 2000, 46, 1-8. [CrossRef]

10. Le Clef, E.; Kemper, T. Sunflower Seed Preparation and Oil Extraction Sunflower; Elsevier: Amsterdam, The Netherlands, 2015; pp. 187-226.

11. Lomascolo, A.; Uzan-Boukhris, E.; Sigoillot, J.C.; Fine, F. Rapeseed and sunflower mean: A review on biotechnology status and challenges. Appl. Microbiol. Biotechnol. 2012, 95, 1105-1114. [CrossRef]

12. Deli, S.; Farah Masturah, M.; Tajul Aris, Y.; Wan Nadiah, W.A. The effects of physical parameters of the screw press oil expeller on oil yield from Nigella sativa L. seeds. Int. Food Res. J. 2011, 18, 1367-1373.

13. Pradhan, R.C.; Mishra, S.; Naik, S.N.; Bhatnagar, N.; Vijay, V.K. Oil expression from Jatropha seeds using a screw press expeller. Biosyst. Eng. 2011, 109, 158-166. [CrossRef]

14. Mrema, G.C.; McNulty, P.B. Mathematical model of mechanical oil expression from oilseeds. J. Agric. Eng. Res. 1985, 31, 361-370. [CrossRef]

15. Khan, L.M.; Hanna, M.A. Expression of oil from oilseeds-A review. J. Agric. Eng. Res. 1983, 28, 495-503. [CrossRef]

16. Savoire, R. Screw Pressing Application to Oilseeds; Elsevier: Amsterdam, The Netherlands, 2017; pp. 1-3.

17. Ali, M.; Watson, I.A. Comparison of oil extraction methods, energy analysis and biodiesel production from flax seeds. Int. J. Energy Res. 2014, 38, 614-625. [CrossRef]

18. Willems, P.; Kuipers, N.; De Haan, A. Hydraulic pressing of oilseeds: Experimental determination and modeling of yield and pressing rates. J. Food Eng. 2008, 89, 8-16. [CrossRef]

19. Bargale, P.C.; Ford, R.J.; Sosulski, F.W.; Wulfsohn, J.; Irudayaraj, J. Mechanical oil expression from extruded soybean samples. J. Am. Oil Chem. Soc. 1999, 76, 223-229. [CrossRef]

20. Bhuiya, M.M.K.; Rasul, M.; Khan, M.; Ashwath, N.; Mofijur, M. Comparison of oil extraction between screw press and solvent (n-hexane) extraction technique from beauty leaf (Calophyllum inophyllum L.) feedstock. Ind. Crop. Prod. 2020, 114, 112024. [CrossRef]

21. Awolu, O.O.; Manohar, B. Quantitative and qualitative characterization of mango kernel seed oil extracted using supercritical $\mathrm{CO}_{2}$ and solvent extraction techniques. Heliyon 2019, 5, e03068. [CrossRef]

22. Bogaert, L.; Mathieu, H.; Mhemdi, H.; Vorobiev, E. Characterization of oilseeds mechanical expression in an instrumented pilot screw press. Ind. Crop. Prod. 2018, 121, 106-113. [CrossRef]

23. Evon, P.H.; Kartika, I.A.; Cerny, M.; Rigal, L. Extraction of oil from jatropha seeds using a twin-screw extruder: Feasibility study. Ind. Crop. Prod. 2013, 47, 33-42. [CrossRef]

24. Gutierrez, L.F.; Ratti, C.; Belkacemi, K. Effects of drying method on the extrusion yields and quality of oils from Quebec sea buckthorn (Hippophae rhamnoides L.) seeds and pulp. Food Chem. 2008, 106, 896-904. [CrossRef]

25. Okeleye, A.A.; Betiku, E. Kariya (Hildegardia barteri) seed oil extraction: Comparative evaluation of solvent, modeling, and optimization techniques. Chem. Eng. Commun. 2019, 206, 1181-1198. [CrossRef]

26. Atabani, A.E.; Mahlia, T.M.I.; Badruddin, I.A.; Masjuki, H.H.; Chong, W.T.; Lee, K.T. Investigation of physical and chemical properties of potential edible and non-edible feedstocks for biodiesel production, a comparative analysis. Renew. Sustain. Energy Rev. 2013, 21, 749-755. [CrossRef]

27. Kostic, M.D.; Jokovic, N.M.; Stamenkovic, O.S.; Rajkovic, K.M.; Milic, P.S.; Veljkovic, V.B. Optimization of hempseed oil extraction by n-hexane. Ind. Crop. Prod. 2013, 48, 133-143. [CrossRef]

28. Sayyar, S.; Abidin, Z.Z.; Yunus, R.; Muhammad, A. Extraction of oil from Jatropha seeds-optimization and kinetics. Am. J. Appl. Sci. 2009, 6, 1390. [CrossRef] 
29. Mani, S.; Jaya, S.; Vadivambal, R. Optimization of solvent extraction of moringa (Moringa oleifera) seed kernel oil using response surface methodology. Food Bioprod. Process. 2007, 85, 328-335. [CrossRef]

30. Stanisavljevic, S.; Lakicevic, D.; Velickovic, M.; Lazic, M.; Veljkovic, V. The extraction of oil from tobacco (Nicotiana tabacum L.) seeds. Chem. Ind. Chem. Eng. Q. 2007, 13, 41-50. [CrossRef]

31. Albertos, I.; Martin-Diana, A.B.; Sanz, M.A.; Barat, J.M.; Diez, A.M.; Jaime, I.; Rico, D. Effect of high pressure processing or freezing technologies as pretreatment in vacuum fried carrot snacks. Innov. Food Sci. Emerg. Technol. 2016, 33, 115-122. [CrossRef]

32. Fan, L.P.; Min, Z.; Gong-Nian, X.; Jin-Cai, S.; Quin, T. The optimization of vacuum frying to dehydrate carrot chips. Int. J. Food Sci. Technol. 2005, 40, 911-919. [CrossRef]

33. Shyu, S.; Hau, L.; Hwang, L.S. Effects of processing conditions on the quality of vacuum-fried carrot chips. J. Sci. Food Agric. 2005, 85, 1903-1908. [CrossRef]

34. Chen, X.; Ma, L.; Guo, T.; Yu, Y.; Li, X.; Xia, W.; Zhang, Y. Effects of freezing-thawing pretreatment combined with liquid nitrogen and dilute acid on the gelatinization of collagen. Int. J. Biol. Macromol. 2018, 118, 435-441. [CrossRef]

35. Lili, W.; Yeming, C.; Zaigui, L. The effects of freezing on soybean microstructure and qualities of soymilk. J. Food Eng. 2013, 116, 1-6. [CrossRef]

36. Noh, E.J.; Park, S.Y.; Pak, J.I.; Hong, S.T.; Yun, S.E. Coagulation of soymilk and quality of tofu as affected by freeze treatment of soybeans. Food Chem. 2005, 91, 715-721. [CrossRef]

37. Gao, Y.; Wang, L.; Li, Z. Effects of freezing process on water absorption rate and cooking hardness of black beans. Acad. Period. Farm Prod. Process. 2011, 12, 22-24.

38. Danso-Boateng, E. Effect of Enzyme and Heat Pretreatment on Sunflower Oil Recovery Using Acqueous and Hexane Extractions. Int. J. Chem. Biol. Eng. 2011, 4, 28-34.

39. Sirisomboon, P.; Kitchaiya, P. Physical properties of Jatropha curcas L. kernels after heat treatments. Biosyst. Eng. 2009, 102, 244-250. [CrossRef]

40. Ogunsina, B.S.; Owolarafe, O.K.; Olatunde, G.A. Oil point pressure of cashew (Anacardium occidentale) kernels. Int. Agrophys. 2008, 22, 53-59.

41. Adeeko, K.A.; Ajibola, O.O. Processing factors affecting yield and quality of mechanically expressed groundnut oil. J. Agric. Eng. Res. 1990, 45, 31-43. [CrossRef]

42. Adedeji, A.; Ngadi, M. Impact of freezing method, frying and storage on fat absorption kinetics and structural changes of parfried potato. J. Food Eng. 2018, 218, 24-32. [CrossRef]

43. Singh, R.P.; Heldman, D.R. Introduction to Food Engineering, 5th ed.; Elsevier: Boston, MA, USA, $2014 ;$ p. 521.

44. Sun, D.W.; Li, B. Microstructural change of potato tissues frozen by ultrasound-assisted immersion freezing. J. Food Eng. 2003, 57, 337-345. [CrossRef]

45. Delgado, A.E.; Sun, D.W. Heat and mass transfer models for predicting freezing processeea review. J. Food Eng. 2001, 47, 157-174. [CrossRef]

46. Masella, P.; Guerrini, L.; Angeloni, G.; Spadi, A.; Baldi, F. Freezing/storing olives, consequences for extra virgin olive oil quality. Int. J. Refrig. 2019, 106, 24-32. [CrossRef]

47. Garcio-Vico, L.; Garcia-Rodriguez, R.; Sanz, C.; Perez, A.G. Biochemical aspects of olive freezing-damage: Impact on the phenolic and volatile profiles of virgin olive oil. LWT Food Sci. Technol. 2017, 86, 240-246. [CrossRef]

48. Rubalya, V.S.; Mukesh, K.V.; Devasena, T. Selected rheological characteristics and physicochemical properties of vegetable oil affected by heating. Int. J. Food Prop. 2015, 19, 1852-1862.

49. Mousavi, K.; Shoeibi, S.; Ameri, M. Effects of storage conditions and PET packaging on quality of edible oils in Iran. Adv. Environ. Biol. 2012, 6, 694-701.

50. Jinfeng, P.; Huixing, S.; Juan, Y.; Yongkang, L. Changes in physiochemical properties of myofibrillar protein from silver Carp (Hypophthalmichthys Mollitrix) during heat treatment. J. Food Biochem. 2011, 35, 939-952.

51. Choe, E.; Min, D.B. Chemistry of deep fat frying oils. J. Food Sci. 2007, 72, 77-86. [CrossRef] [PubMed]

52. Al-Kahtani, H.A. Survey of quality of used frying oils from restaurants. J. Am. Oil Chem. Soc. 1991, 68, 857-862. [CrossRef]

53. Wang, N.; Ma, T.; Yu, X.; Xu, L.; Zhang, R. Determination of peroxide values of edible oils by ultraviolet spectrometric method. Food Anal. Methods 2016, 9, 1412-1417. [CrossRef]

54. Shiozawa, S.; Tanaka, M.; Ohno, K.; Nagao, Y.; Yamada, T. Reevaluation of peroxide value as an indicator of the quality of edible oils. J. Food Hyg. Soc. Jpn. 2007, 48, 51-57. [CrossRef] 
55. Saad, B.; Wai, W.T.; Lim, B.P.; Saleh, M.I. Flow injection determination of peroxide value in edible oils using triiodide detector. Anal. Chem. Acta 2006, 565, 261-270. [CrossRef]

56. Dermis, S.; Can, S.; Dogru, B. Determination of peroxide values of some fixed oils by using the mFOX method. Spectrosc. Lett. 2012, 45, 359-363. [CrossRef]

57. Liu, Y.; Li, J.; Cheng, Y.; Liu, Y. Effect of frying oils' fatty acid profile on quality, free radical and volatiles over deep-frying process: A comparative study using chemometrics. LWT Food Sci. Technol. 2019, 101, 331-341. [CrossRef]

58. Gomna, A.; N'Tsoukpoe, K.E.; Le Pierres, N.; Coulibaly, Y. Review of vegetable oils behaviour at high temperature for solar plants: Stability, properties and current applications. Sol. Energy Mater. Sol. Cells 2019, 200. [CrossRef]

59. Uitterhaegen, E.; Evon, P. Twin-screw extrusion technology for vegetable oil extraction: A review. J. Food Eng. 2017, 212, 190-200. [CrossRef]

60. Karaj, S.; Muller, J. Optimizing mechanical oil extraction of Jatropha curcas L. seeds with respect to press capacity, oil recovery and energy efficiency. Ind. Crop. Prod. 2011, 34, 1010-1016.

61. Rombaut, N.; Savoire, R.; Thomasset, B.; Castello, J.; Hecke, E.V.; Lanoiselle, J.-L. Optimization of oil yield and oil total phenolic content during grape seed cold screw pressing. Ind. Crop. Prod. 2015, 63, 26-33. [CrossRef]

62. Demirel, C.; Kabutey, A.; Herak, D.; Gurdil, G.A.K. Numerical estimation of deformation energy of selected bulk oilseeds in compression loading. IOP Conf. Ser. Mater. Sci. Eng. 2017, 237, 1-5. [CrossRef]

63. Kabutey, A.; Herak, D.; Choteborsky, R.; Dajbych, O.; Sigalingging, R.; Akangbe, O.L. Compression behaviour of bulk rapeseed: Effects of heat treatment, force, and speed. Int. J. Food Prop. 2017, 20, S654-S662. [CrossRef]

64. Divisova, M.; Herak, D.; Kabutey, A.; Sigalingging, R.; Svatonova, T. Deformation curve characteristics of rapeseeds and sunflower seeds under compression loading. Sci. Agric. Bohem. 2014, 45, 180-186.

65. Munson-Mcgee, S.H. D-optimal experimental designs for uniaxial expression. J. Food Process Eng. 2014, 37, 248-256. [CrossRef]

66. Herak, D.; Gürdil, G.; Sedlacek, A.; Dajbybch, O.; Simanjuntak, S. Energy demands for pressing jatropha curcas L. seeds. Biosyst. Eng. 2010, 106, 527-534. [CrossRef]

67. Kabutey, A.; Herak, D.; Ambarita, H.; Sigalingging, R. Modeling of linear and non-linear compression processes of sunflower bulk oilseeds. Energies 2019, 12, 2999. [CrossRef]

68. Kabutey, A.; Herak, D.; Mizera, C.; Hrabe, P. Theoretical analysis of force, pressure and energy distributions of bulk oil palm along the screwline of a mechanical screw press FL 200. Agron. Res. 2019, 17, 1927-1941.

69. ISI. Indian Standard Methods for Analysis of Oilseeds. In Indian Standard Institute; IS:3579; ISI: New Delhi, India, 1966.

70. Blahovec, J. Agromatereials Study Guide; Czech University of Life Sciences Prague: Prague, Czech Republic, 2008.

71. Niu, L.; Li, J.; Chen, M.S.; Xu, Z.F. Determination of oil contents in Sacha inchi (Plukenetia volubilis) seeds at different developmental stages by two methods: Soxhlet extraction and time-domain nuclear magnetic resonance. Ind. Crop. Prod. 2014, 56, 187-190. [CrossRef]

72. Danlami, J.M.; Arsad, A.; Zaini, M.A.A. Characterization and process optimization of castor oil (Ricinus communis L.) extracted by the soxhlet method using polar and non-polar solvents. J. Taiwan Inst. Chem. Eng. 2015, 47, 99-104. [CrossRef]

73. Herak, D.; Blahovec, J.; Kabutey, A. Analysis of the axial pressing of bulk jatropha curcas L. seeds using reciprocal slope transformation. Biosyst. Eng. 2014, 121, 67-76. [CrossRef]

74. Chakespari, A.G.; Rajabipour, A.; Mobli, H. Anisotropic relaxation and creep properties of apple (cv. Shafi Abadi and Golab Kohanz). Adv. J. Food Sci. Technol. 2010, 2, 200-205.

75. Demirel, C.; Gurdil, G.A.K.; Kabutey, A.; Wasserbauer, M. Comparing energy demand of densified briquettes of ground and unground hazelnut husks under compression loading. IOP Conf. Ser. Earth Environ. Sci. 2019, 260, 1-5. [CrossRef]

76. Hernandez-Santos, B.; Rodriguez-Miranda, J.; Herman-Lara, E.; Torruco-Uco, J.G.; Carmona-Garcia, R.; Juarez-Barrientos, J.M.; Chavez-Zamudio, R.; Martinez-Sanchez, C.E. Effect of oil extraction assisted by ultrasound on the physiochemical properties and fatty acid profile of pumpkin seed oil (Cucurbita pepo). Ultrasound Sonochem. 2016, 31, 429-436. [CrossRef] 
77. Orozco, F.D.A.; Sousa, A.C.; Araujo, M.C.U.; Domini, C.E. A new flow UV-Vis kinetics spectrophotometric method based on photodegradative reaction for determining the oxidative stability of biodiesel. Fuel 2020, 26, 116-197.

78. Chatepa, L.E.C.; Uluko, H.; Masamba, K. Comparison of oil quality extracted from selected conventional and non conventional sources of vegetable oil from Malawi. Afr. J. Biotechnol. 2019, 18, 171-180.

79. StatSoft Inc. (1995). STATISTICA for Windows. StatSoft Inc.: Tulsa, OK, USA, 2013.

80. Kabutey, A.; Herak, D.; Mizera, C.; Wasserbauer, M. Assessment of undulation behaviour of rape and sunflower bulk oilseeds under compression loading. IOP Conf. Ser. Mater. Sci. Eng. 2018, 420, 1-6. [CrossRef]

81. Okene, E.O.; Evbuomwan, B.O. Solvent extraction and characteristics of oil from coconut seeds using alternative solvents. Int. J. Eng. Technol. Res. 2014, 2, 135-138.

82. Adejumo, B.A.; Inaede, S.G.; Adamu, T.S. Effect of moisture content on the yield and characteristics of oil from Moringa oleifera seeds. Acad. Res. Int. 2013, 4, 160.

83. Aksoy, F.; Yabanova, I.; Bayrakceken, H.; Aksoy, I. Estimating the dynamic viscosity of vegetable oils using artificial neural networks. Energy Sources Part Recovery Util. Environ. Eff. 2014, 36, 858-865. [CrossRef]

84. Nkafamiya, I.I.; Maina, H.M.; Osemeahon, S.A.; Modibbo, U.U. Percentage oil yield and physiochemical properties of different groundnut species (Arachis hypogaea). Afr. J. Food Sci. 2010, 4, 418-421.

85. Kumar, K.A.; Viswanathan, K. Study of UV Transmission through a Few Edible Oils and Chicken Oil. J. Spectrosc. 2013. [CrossRef]

86. Kaewwinud, N.; Khokhajaikiat, P.; Boonma, A. Effect of biomass characteristics on durability of Cassava residues pellets. Res. Agric. Eng. 2018, 64, 15-19.

(C) 2020 by the authors. Licensee MDPI, Basel, Switzerland. This article is an open access article distributed under the terms and conditions of the Creative Commons Attribution (CC BY) license (http://creativecommons.org/licenses/by/4.0/). 